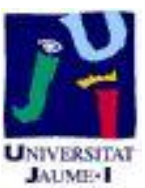

Título artículo / Títol article: Perspectives and Potential Applications of Mitochondria-Targeted Antioxidants in Cardiometabolic Diseases and Type 2 Diabetes

Autores / Autors

Rocha, Milagros; Apostolova Atanasovska, Nadezda; Herance, Jose Raul; Rovira Llopis, Susana ;

Hernandez Mijares, Antonio; Víctor, Víctor M.

Revista:

Medicinal Research Reviews

Versión / Versió:

Post-print

Cita bibliográfica / Cita

ROCHA, Milagros, et al. Perspectives and Potential bibliogràfica (ISO 690):

Applications of Mitochondria - Targeted

Antioxidants in Cardiometabolic Diseases and Type 2

Diabetes. Medicinal research reviews, 2014, vol. 34, no 1 , p. 160-189.

url Repositori UJI:

http://hdl.handle.net/10234/96534 


\begin{tabular}{|l|l|l|l|l|}
\hline \multirow{2}{*}{ apta 1 aptara } & MED & med21285 & Dispatch: April 23, 2013 & CE: \\
\cline { 2 - 5 } & Journal & MSP No. & No. of pages: 30 & PE: XXXXX \\
\hline
\end{tabular}

\title{
Perspectives and Potential Applications of Mitochondria-Targeted Antioxidants in Cardiometabolic Diseases and Type 2 Diabetes
}

\author{
Milagros Rocha, ${ }^{1,2,3 *}$ Nadezda Apostolova, ${ }^{4 *}$ Raul Herance, ${ }^{5}$ Susana Rovira-Llopis, ${ }^{1,2}$ \\ Antonio Hernandez-Mijares, ${ }^{1,2,3,6}$ and Victor M. Victor ${ }^{1,2,3,4,7 *}$ \\ ${ }^{1}$ Fundacion para la Investigacion Sanitaria y Biomedica de la Comunidad Valenciana FISABIO, Valencia, Spain \\ ${ }^{2}$ University Hospital Doctor Peset, Endocrinology Service, Valencia, Spain \\ ${ }^{3}$ INCLIVA Foundation, Valencia, Spain \\ ${ }^{4}$ Department of Pharmacology and CIBER CB06/04/0071 Research Group, CIBER Hepatic and Digestive \\ Diseases, University of Valencia, Valencia, Spain \\ ${ }^{5}$ CRC-Centre d'Imatge Molecular (CRC-CIM), Parc de Recerca Biomedica de Barcelona (PRBB), Barcelona, \\ Spain \\ ${ }^{6}$ Department of Medicine, University of Valencia, Valencia, Spain \\ ${ }^{7}$ Department of Physiology, University of Valencia, Valencia, Spain \\ Published online in Wiley Online Library (wileyonlinelibrary.com). \\ DOI 10.1002/med.21285
}

\begin{abstract}
There is abundant evidence to suggest that mitochondrial dysfunction is a main cause of insulin resistance and related cardiometabolic comorbidities. On the other hand, insulin resistance is one of the main characteristics of type 2 diabetes, obesity, and metabolic syndrome. Lipid and glucose metabolism require mitochondria to generate energy, and when $\mathrm{O}_{2}$ consumption is low due to inefficient nutrient oxidation, there is an increase in reactive oxygen species, which can impair different types of molecules, including DNA, lipids, proteins, and carbohydrates, thereby inducing proinflammatory processes. Factors which contribute to mitochondrial dysfunction, such as mitochondrial biogenesis and genetics, can also lead to insulin resistance in different insulin-target tissues, and its association with mitochondrial dysfunction can culminate in the development of cardiovascular diseases. In this context, therapies that improve mitochondrial function may also improve insulin resistance. This review explains mechanisms of mitochondrial function related to the pathological effects of insulin resistance in different tissues. The pathogenesis of cardiometabolic diseases will be explained from a mitochondrial perspective

*These authors have contributed equally to this work.

Contract grant sponsor: PI10/1195; Contract grant sponsor: PI 12/1982; Contract grant sponsor: CIBERehd CB06/04/0071; Contract grant sponsor: PROMETEO 2010/060; Contract grant sponsor: ACOMP/2012/042; Contract grant sponsor: ACOMP/2012/045; Contract grant sponsor: European Regional Development Fund (ERDF). Additional corresponding author: Milagros Rocha, E-mail: milagros.rocha@uv.es.

Correspondence to: Victor M. Victor, University Hospital Doctor Peset, Avda Gaspar Aguilar 90, 46017 Valencia, Spain. E-mail: victor.victor@uv.es.
\end{abstract}




\section{2 - ROCHA ET AL.}

and the potential beneficial effects of mitochondria-targeted antioxidants as a therapy for modulating mitochondrial function in cardiometabolic diseases, especially diabetes, will also be considered. (c) 2013 Wiley Periodicals, Inc. Med. Res. Rev., 00, No. 0, 1-30, 2013

Key words: cardiometabolic disease; diabetes; insulin resistance; mitochondria; oxidative stress

\section{INTRODUCTION}

Cardiometabolic diseases, which include multiple pathologies such as type 2 diabetes, metabolic syndrome, and coronary heart disease, are a growing health problem worldwide. ${ }^{1}$ For example, diabetes is associated with numerous complications that severely affect the quality of life and life expectancy of patients, such as macro- and microvascular impairments. Currently, around 300 million people worldwide have diabetes, and this figure is expected to rise to 500 million over the following years. Diabetes is related to an increase in the risk of cancer and other deleterious conditions, with all their physical and clinical consequences. The number of people with cardiometabolic syndrome, a key precursor to metabolic diseases such as diabetes and subsequent cardiovascular complications, is also growing. ${ }^{2}$ Furthermore, insulin resistance, the main characteristic of cardiometabolic syndrome, is associated with activation of the tissue renin-angiotensin system. ${ }^{3}$ The principal metabolic action of insulin is to promote glucose uptake in skeletal muscle and to suppress glucose production in the liver, thereby maintaining glucose homeostasis. On the other hand, insulin resistance, defined as a decreased sensitivity to these metabolic actions, correlates with type 2 diabetes and cardiovascular diseases (CVDs). ${ }^{4}$

Mitochondria play a key role in the metabolism by regulating energy homeostasis through the metabolization of nutrients, producing ATP and generating heat (Fig. 1). Mitochondrial dysfunction is characterized by an inhibition of mitochondrial $\mathrm{O}_{2}$ consumption, changes in the mitochondrial membrane potential $\left(\Delta \Psi_{\mathrm{m}}\right)$, and a reduction in ATP levels due to an imbalance between energy intake and expenditure. 5 (Fig. 2). In fact, changes in $\Delta \Psi_{\mathrm{m}}$ may be due to both reduced activity in the electron transport chain (ETC) complexes and therefore reduced pumping of protons, or increased uncoupling produced by the activity of uncoupling proteins (UCPs) or the ADP/ATP translocator (also called adenine nucleotide translocase, ANT).

Different factors, both genetic and environmental (exercise, diet, and stress) can affect insulin sensitivity and regulate mitochondrial function. ${ }^{6,7}$ In addition, insulin resistance has been associated with mitochondrial dysfunction in several tissues, including lung, spleen, liver, heart, skeletal muscle, ${ }^{8-10}$ and even in cells, such as leukocytes in type 2 diabetes. ${ }^{11}$ Therefore, insulin resistance due in part by mitochondrial dysfunction may be a common pathophysiologic etiology of many widespread chronic diseases.

\section{MITOCHONDRIA}

Mitochondria play a key role in the life and death of cells, which make them a major target for cytoprotective pharmacological agents. Physiologically, mitochondria perform several fundamental regulatory processes in the cell (Fig. 1). They consume approximately $92-95 \%$ of cellular $\mathrm{O}_{2}$ in the process of oxidative phosphorylation (OXPHOS). ETC is located in the inner membrane of the mitochondrion, and the production of ATP requires two steps: NADH (or FADH ${ }_{2}$ ) oxidation and ADP phosphorylation, which produces ATP. NADH and $\mathrm{FADH}_{2}$ are generated by glycolysis and $\beta$-oxidation of fatty acids (FAs) and are oxidized to FAD or $\mathrm{NAD}^{+}$. Electrons from $\mathrm{FADH}_{2}$ and NADH are transferred through different respiratory chain complexes to $\mathrm{O}_{2}$, which generates $\mathrm{H}_{2} \mathrm{O}$. The driving force by which $\mathrm{F}_{0} \mathrm{~F}_{1}$-ATPase 


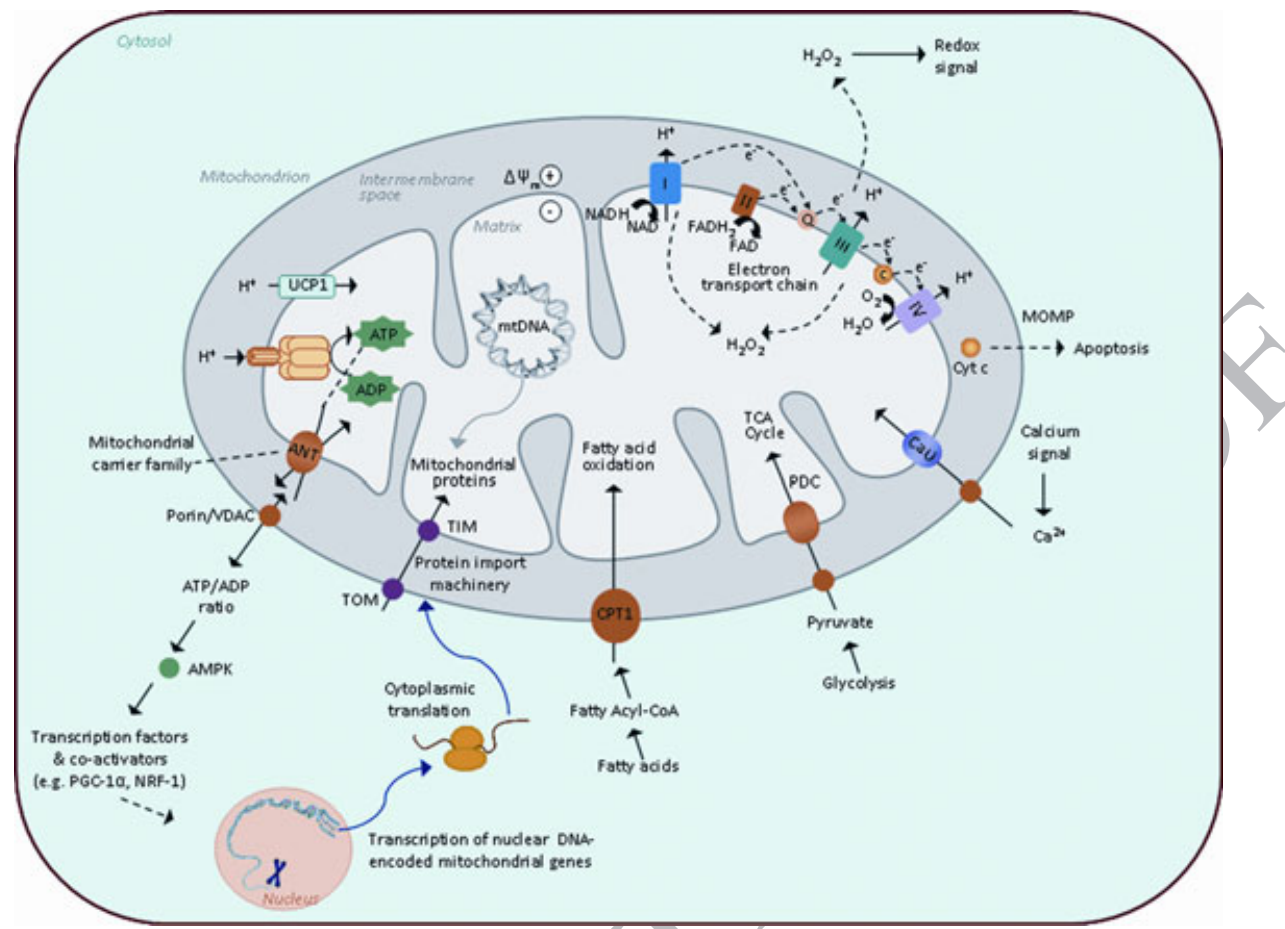

Figure 1. Mitochondrial function in health. The mitochondrial proteome consists of mtDNA and nuclear DNAencoded proteins. Cytosolic fatty acids and pyruvate fuel the catabolic processes in the mitochondrion $(\beta$ oxidation and the Krebs cycle), giving rise to oxidable susbstrates (succinate, $\mathrm{NADH}$ ) of the electron transport chain. The respiratory chain complexes, associated with the IMM, transfer electrons from an electron donor to an electron acceptor, thus creating a transmembrane electrochemical gradient. The electrochemical energy from this transmembrane proton gradient is harnessed by ATP synthase (Complex V) to combine ADP and inorganic phosphate $\left(\mathrm{P}_{\mathrm{i}}\right)$ and produce ATP, which is transferred through the IMM by ANT. The ADP/ATP ratio is sensed in the cytosol by AMPK, which modulates many metabolic pathways with the aim of preserving the energy of homeostasis. The electron flow along the respiratory chain generates moderate amounts of ROS, which act as signaling and regulatory molecules. UCPs are mitochondrial transporters located at the inner membrane that dissipate the proton gradient, thus, displaying metabolic and thermogenic activity. AMPK, AMP-activated protein kinase; ANT, ADP/ATR translocator or adenine nucleotide translocase; CaU, calcium uniporter; CPT1, carnitine palmitoyltransferase 1; MOMP, mitochondrial outer membrane permeabilization; mtDNA, mitochondrial DNA; NRF-1, nuclear respiratory factor 1; PDC, pyruvate decarboxylase; PGC1- $\alpha$, peroxisome proliferatoractivated receptor gamma coactivator-1-alpha; ROS, reactive oxygen species; TCA, tricarboxilic acid cycle; TIM, translocase of the inner membrane; TOM, translocase of the outer membrane; UCPS, uncoupling proteins; VDAC, voltage-dependent anion channel.

(ATP synthase) produces ATP is the proton gradient across the membrane. A portion of the electrons at ETC can leak, thus causing generation of reactive oxygen species (ROS), molecules which play an important role in the development of several human diseases. ${ }^{12-14}$

There are different mechanisms by which mitochondria can produce heat, such as the proton leak, which undermines the proton-motive force, thus generating heat instead of ATP. This effect can be significant in different physiological and pathological situations. It has been demonstrated that UCPs (Fig. 1) can reduce the proton gradient. ${ }^{15}$ UCPs are a family of inner mitochondrial membrane proteins that are thought to control several aspects of mitochondrial function, such as ROS generation, FA homeostasis, and regulate mitochondrial biogenesis. UCP1 is expressed mainly in brown adipose tissue, UCP2 is ubiquitous, and UCP3 is present in skeletal muscle. ${ }^{16} \mathrm{UCP} 1$, which counts for up to $10 \%$ of total membrane protein content, regulates adaptive thermogenesis, whereas UCP2 and UCP3 do not play a key role in 


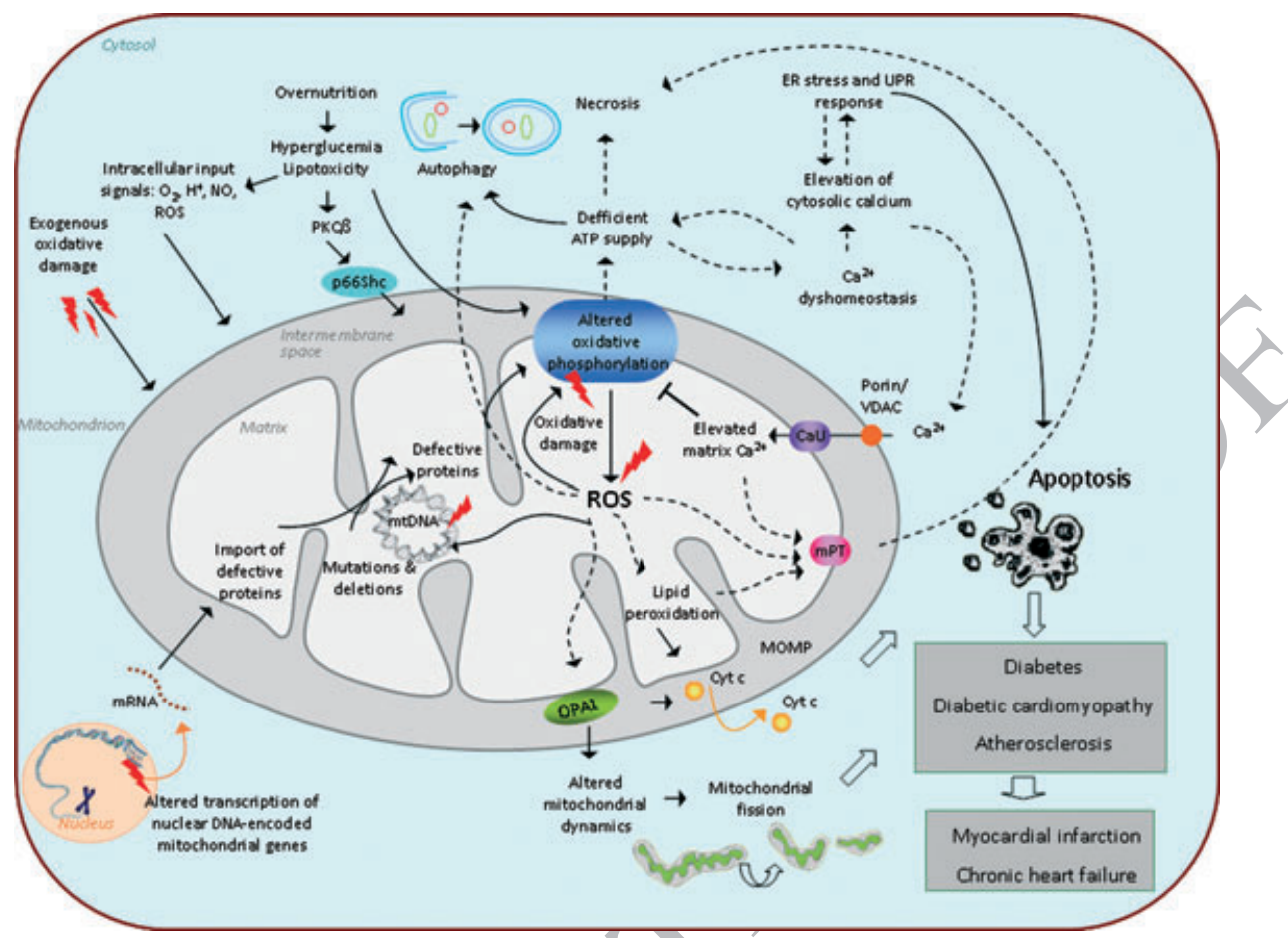

Figure 2. Mitochondrial (dys) function in disease with a focus on cardiometabolic pathologies. Mutations in mtDNA and altered transcription of nuclear genes encoding mitochondrial proteins give rise to dysfunctional mitochondrial proteome. This leads to a defect in the mitochondrial OXPHOS process, culminating in a decreased level of ATP generation. The insufficient ATP supply can provoke necrotic cell death through a major "energetic catastrophe." Altered/impaired electron transport leads to augmented generation of ROS, which damages biological macromolecules including DNA (causing mtDNA mutations) and lipids (lipid peroxidation). Mitochondrial dysfunction can also be triggered by toxic exogenous stimuli and increased input of nutrients, and is influenced by various cytosolic signaling molecules. Impaired mitochondria present altered mitochondrial morphology and dynamics (through modification of the activity of OPA1). Damaged mitochondria can signal for autophagy (and the specific form, mitophagy) and induce programs of cell death, such as apoptosis (through mitochondrial permeability transition and release of mitochondrial proapoptotic proteins such as cyt $c$ ). Mitochondrial dysfunction also involves altered calcium handling in close relation with ER stress and activation of the UPR response. $\mathrm{CaU}$, calcium uniporter; cyt $c$, cytochrome $c$; ER, endoplasmic reticulum; MOMP, mitochondrial outer membrane permeabilization; MPT, mitochondrial permeability transition; mtDNA, mitochondrial DNA; OPA1, optic atrophy gene 1; PKC $\beta$, protein kinase C-beta; ROS, reactive oxygen species; UPR, unfolded protein response.

thermogenesis, as knockout mice for UCP2 and UCP3 have a normal basal proton conductance, adequate response to cold and body weight. ${ }^{17}$ In general, abundant evidence suggests that UCPs play an important role in mitochondrial function by regulating generation of both ROS and heat, which underscores the fact the energy balance of mitochondria is key to cellular function. The role of UCPs in cardiometabolic diseases is still not fully clear. By hyperpolarizing the inner mitochondrial membrane, UCPs may protect the cell through decreasing the production of mitochondrial ROS and regulating mitochondrial apoptosis signals. Indeed, mice overexpressing UCP2 or UCP3 have been shown to exhibit decreased ROS production, ${ }^{18}$ higher metabolic rate, and to be protected against weight gain and insulin resistance. ${ }^{19}$ Also, there is abundant although discrepant evidence linking the common functional promoter polymorphism of $U C P 2,-866 \mathrm{G}>\mathrm{A}$ (rs659366) and changes in the risk of type 2 diabetes, obesity, and coronary artery disease. ${ }^{20,21}$

The correlation between UCPs and lipid metabolism regarding cardiometabolic pathologies merits special mention. It has been described that in patients with heart disease there is 
a high concentration of circulating free fatty acid (FFAs) and this is inversely correlated with myocardial phosphocreatine:ATP ratio, suggesting a cardiac energy deficit. ${ }^{22}$ Several studies have pointed out that there is a positive correlation between the content of cardiac UCPs and the concentration of circulating FFAs, explaining the energy deficit observed in the damaged heart. ${ }^{22}$ In addition to this, an increase in UCPs not always results in uncoupling of mitochondrial respiration from ATP production, as measured by postdepletion phosphocreatine synthesis rate. ${ }^{23}$

There is also evidence that UCPs are involved in the translocation of FA anions away from the mitochondrial matrix. When not all FAs can enter mitochondria via carnitine palmitoyltransferase as oxidizable fatty acyl-coenzyme A (acyl-CoA) esters, the excess can enter the mitochondrial matrix via a flip-flop mechanism in their unesterified (nonoxidizable) form where they become deprotonated. The resultant FA anions can neither be oxidized nor leave the matrix due to the proton gradient and are therefore locked in the matrix where they are harmful to mitochondria. UCPs can act as outward transporters of FAs, thereby protecting mitochondria in conditions characterized by an oversupply of FAs. ${ }^{24}$ In line with this function, UCP content inversely relates to oxidative capacity. Hence, concentrations of UCP are 14-fold lower in cardiac muscle than in glycolytic muscle. ${ }^{25}$

Increased levels of fat loading in mitochondria by consumption of a high fat diet can upregulate UCPs in cardiac muscle. ${ }^{26}$ Considering UCPs as an FA anion exporter, the positive association between cardiac UCPs content and plasma FFA concentrations can be considered a beneficial rather than an unfavorable-adaptive response, attempting to protect the damaged heart from lipotoxicity. In this context, inhibition of fat oxidation, which has been proposed as a treatment for heart disease, can result in the upregulation not downregulation of expression of UCPs. These results point out that increased UCPs levels are beneficial for the damaged human heart, although can be detrimental in $\beta$-cells due to less insulin secretion.

In addition, it is necessary to take into account that the nutrient oversupply, particularly that of FAs, can induce OXPHOS uncoupling. For example, feeding animals with a high-fat diet for several weeks is sufficient to reduce the mitochondrial rate of ATP synthesis. ${ }^{27}$ In another study, it was demonstrated that high-fat diet downregulated genes coding for proteins involved in mitochondrial biogenesis and OXPHOS in human skeletal muscle. ${ }^{28}$ In addition, increased levels of FA exposure, as for example in obesity, leads to intracellular accumulation of ceramides and diacylglycerol (DG), which reduces phosphatidylinositol 3-kinase (PI3K) signaling in muscle leading to increased insulin resistance. ${ }^{29}$ Other studies have reported that peroxisome proliferator-activated receptors (PPARs) can bind FAs, particularly polyunsaturated acids, ${ }^{30}$ and PPAR ligands may upregulate UCP2. ${ }^{31}$ In line with this, Bugge et al. have demonstrated that peroxisome proliferator-activated receptor gamma (PPAR $\gamma)$ can activate both UCP2 and UCP3 expression via an enhancer located within the first intron of the UCP3 gene. ${ }^{32}$

Obesity, type 2 diabetes, and insulin resistance can produce a chronic elevation of circulating FAs which can become cytotoxic. The increased basal leakage of electrons and uncoupling in the mitochondria is a serious problem in these conditions because FAs can also cause oxidative stress and alterations in the mitochondrial structure and function. Namely, FA interaction with the membrane carriers can lead to mitochondrial membrane depolarization and result in opening of the permeability transition pore and initiation of apoptosis.

It is very important to point out that there is a transcriptional control of UCP2, for example, by glutamine and for this reason mRNA levels not always refer protein levels. ${ }^{33}$ Thus, it is more worthy to assess the protein levels or perform functional measurements of UCP effects on mitochondria.

Type 2 diabetes and age-related insulin resistance are associated with mitochondrial dysfunction (Fig. 3), ${ }^{34-36}$ and it has been shown that physical activity is one of the central 
6 - ROCHA ET AL.

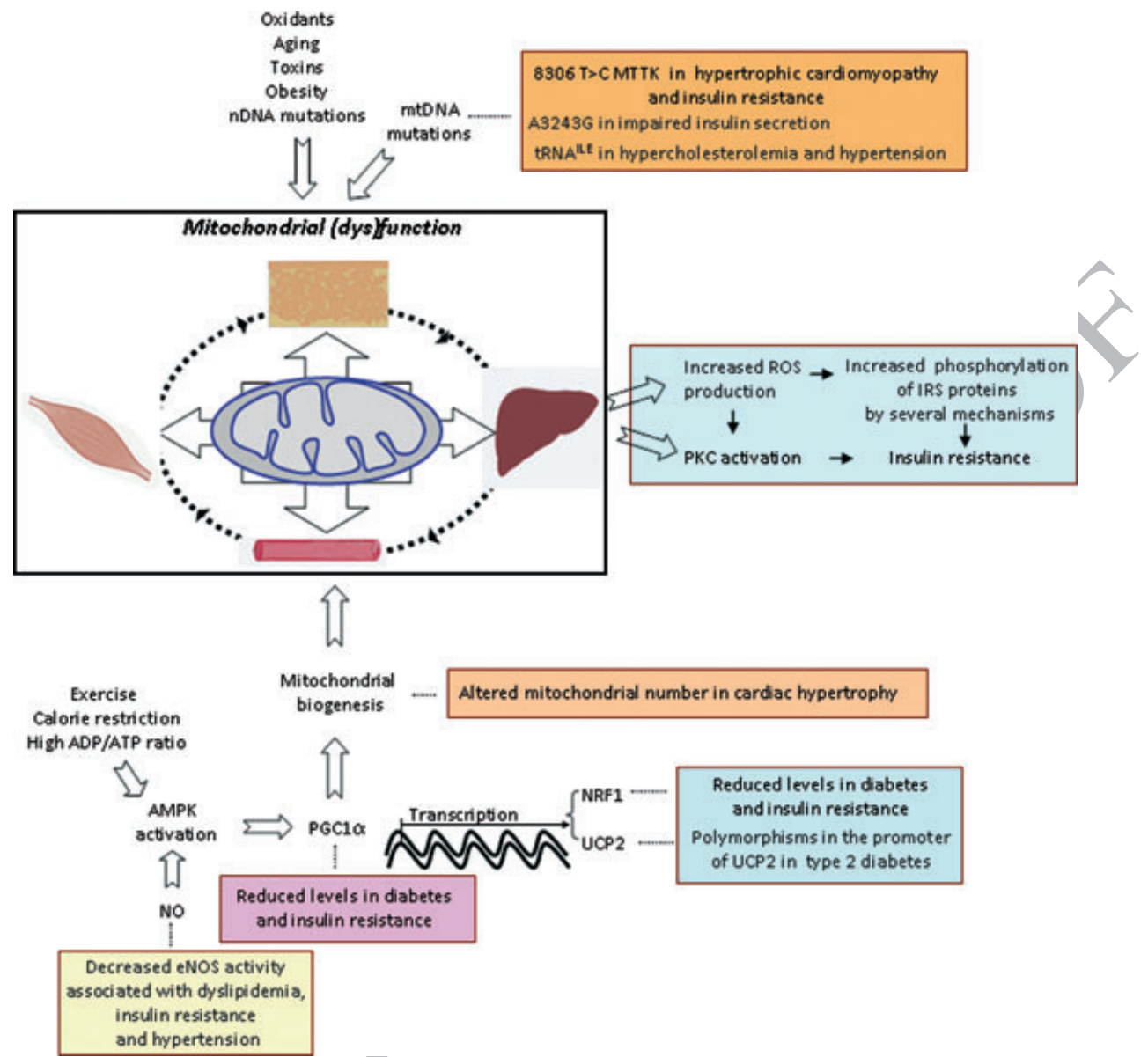

Figure 3. (Patho)physiological factors and mechanisms affecting mitochondrial function with relevance in cardiometabolic diseases. Numerous extrinsic stimuli (oxidants, toxins) and intrinsic conditions (aging, obesity, $\mathrm{nDNA}$, and/or mtDNA mutations, altered mitochondrial biogenesis) affect mitochondrial function. Several indicators associated with mitochondrial dysfunction, such as increased ROS, altered number of mitochondria, and mitochondrial biogenesis, have been documented in cardiometabolic diseases including insulin resistance, diabetes, hypertension, and cardiac hypertrophy. AMPK, AMP-activated protein kinase; eNOS, endothelial nitric oxide synthase; IRS, insulin receptor substrate; mtDNA, mitochondrial DNA; NO, nitric oxide; NRF1, nuclear respiratory factor 1: PGC1 $\alpha$, peroxisome proliferator-activated receptor gamma, coactivator 1 alpha; PKC, protein kinase C; ROS, reactive oxygen species; UPC2, uncoupling protein 2.

determinants of muscle mitochondrial function in type 2 diabetes. ${ }^{36}$ Therefore, mitochondria are emerging as a key target in cardiometabolic disease therapy. Furthermore, it has been hypothesized that there are several important parameters that affect mitochondrial function, including mitochondrial biogenesis, genetic factors, and oxidative stress (leading to insulin resistance).

\section{A. Mitochondrial Biogenesis}

Skeletal muscle of insulin-resistant, obese, or type 2 diabetic humans is characterized by impairment of mitochondrial function and fewer and smaller mitochondria. ${ }^{37-39}$ Indeed, 
mitochondrial oxidative capacity is fully correlated with the number and size of mitochondria. ${ }^{6}$ A decreased OXPHOS is related with reduced expression of mitochondrial proteins encoded by both the nuclear (e.g., succinate dehydrogenase and pyruvate dehydrogenase) and the mitochondrial (e.g., cytochrome c oxidase subunit II) genome (Fig. 2). ${ }^{37}$ In this sense, nuclear respiratory factors (NRFs) and PPAR $\gamma$ play a crucial role in cellular homeostasis. ${ }^{40}$ Peroxisome proliferator-activated receptor gamma, coactivator 1 alpha $(\mathrm{PGC} 1-\alpha)$ is pivotal in transactivating genes essential for homeostasis maintenance ${ }^{41}$ and modulates two fundamental enzymes, namely, sirtuin 1 (SIRT1) and AMP-activated protein kinase (AMPK). During energy depletion, in which there is an increase in the AMP:ATP ratio, PGC1- $\alpha$ activates AMPK. ${ }^{42}$ Moreover, during caloric restriction or exercise there is an increase in NADH content, which upregulates SIRT expression and as a consequence PGC- $1 \alpha .{ }^{43}$

Nitric oxide (NO) is a homeostatic molecule that modulates mitochondrial $\mathrm{O}_{2}$ consumption by inhibiting mitochondrial complex IV, which also regulates mitochondrial biogenesis. ${ }^{44,45} \mathrm{~A}$ number of in vivo and in vitro studies have shown that nitrite activates AMPK to stimulate mitochondrial biogenesis independently of soluble guanylate cyclase, thus, providing evidence that nitrite is a versatile regulator of mitochondrial function, and that nitrite-mediated biogenesis plays a protective role in vascular injury. ${ }^{46}$

The overexpression of PGC- $1 \alpha$ increases both the transcription of genes related to glucose uptake and transport, and $\beta$-oxidation. ${ }^{47}$ PGC- $1 \alpha$ also enhances OXPHOS and promotes the generation of type 1 muscle fiber. ${ }^{48}$ Furthermore, it is involved in the pathogenesis of insulin resistance, and has been related with diabetes when its levels are reduced. ${ }^{49}$

PGC-1 $\alpha$ transcriptionally regulates UCP, thus playing a role in thermogenesis in different tissues, including adipose tissue. ${ }^{50}$ When ATP demand is high, such as during exercise, cold exposure, and fasting, the expression of PGC- $1 \alpha$ is increased ${ }^{51,52}$ (Fig. 3). PGC- $1 \alpha$ is an activator of PPAR $\gamma$ and PPAR $\alpha$ and of several transcription factors, including NRF-1. ${ }^{40,53}$ This factor regulates the expression of different genes that are important for mitochondrial gene expression, such as ETC genes and mitochondrial transcription factor A (TFAM), and for replication of the mitochondrial genome. ${ }^{53}$ Expression of PGC-1 and NRF-1 is reported to be undermined in diabetic and insulin-resistant human subjects, respectively. ${ }^{54}$ Furthermore, PGC-1 expression decreases with age ${ }^{55}$ and the fact that insulin-resistant human patients have small and fewer mitochondria in their skeletal muscle seems to be due to decreased expression of PGC- $1 \alpha$ and PGC- $1 \beta .{ }^{56}$

AMP-activated protein kinase (AMPK) is a major regulator of mitochondrial biogenesis, ${ }^{57}$ which has led to its exploitation for the development of pharmacological agents, such as activators of AMPK [5-amino-1- $\beta$-D-ribofuranosyl-imidazole-4-carboxamide, AICAR], which promote mitochondrial biogenesis through NRFs and PGC- $1 \alpha .{ }^{58}$ AMPK is stimulated by exercise, leading to activation of PGC- $1 \alpha$ by direct phosphorylation of key residues and, consequently, stimulating mitochondrial biogenesis. ${ }^{59,60}$

Several DNA microarray reports have demonstrated that expression of PGC- $1 \alpha$ with its role in mitochondrial biogenesis is responsible for certain metabolic disorders (e.g., insulin resistance and type 2 diabetes) ${ }^{53,57,61}$ (Fig. 3) in that a reduced number of mitochondria leads to insufficient mitochondrial function. Other studies have revealed that mitochondrial $\mathrm{O}_{2}$ consumption is lower in obese and type 2 diabetes subjects than in lean active adults. ${ }^{38}$ It has also been demonstrated that mRNA expression of TFAM, NRFs, PGC- $1 \alpha$, and PGC- $1 \beta$ is similar in insulin-resistant offspring of type 2 diabetes parents and controls, though mitochondrial function is significantly decreased in the former. ${ }^{37}$ These findings suggest that mitochondrial dysfunction involves other components apart from an undermined mitochondrial biogenesis. 
8 - ROCHA ET AL.

\section{B. Genetic Factors}

Mitochondrial proteins are encoded by mitochondrial and nuclear genes. The capacity of mitochondria is determined by their number, state, and size, and by the expression level of OXPHOS subunits. ${ }^{6}$ In this regard, it is of relevance that 13 protein subunits of the mitochondrial ETC are encoded by mitochondrial genes.

The fact that the mitochondrial genome is proximal to sources of ROS gives strength to the idea of its high susceptibility to mutagenesis. ${ }^{35}$ Mitochondrial respiratory chain deficiencies are associated with mutations of mitochondrial DNA (mtDNA), and such inherited dysfunction of the mitochondrial OXPHOS system is the hallmark of many mitochondrial diseases. ${ }^{2,63}$ Several nuclear and mtDNA mutations have been identified as the cause of defects and isolated disorders of individual OXPHOS enzymes, including mitochondrial ATP synthase in patients with cardiovascular-metabolic diseases. ${ }^{64}$ The diseases attributed to familial mtDNA mutations are less common than those related to nuclear DNA defects. This may be a result of mitochondria containing several copies of their genome, as the continuous fusion of mitochondria means that modified genes mix with normal genes, which is a process that characterizes many human diseases. Wilson et al ${ }^{65}$ associated a simple thymidine-to-cytidine mutation in the mitochondrial tRNA ${ }^{\mathrm{ILE}}$ gene with different pathologies, including hypercholesterolemia and hypertension, while Cardaioli et al ${ }^{66}$ demonstrated that the mitochondrial $8306 \mathrm{~T}>\mathrm{C}$ MTTK mutation induces sporadic myopathy, myoclonus, leukoencephalopathy, neurosensory deafness, hypertrophic cardiomyopathy, and insulin resistance (Fig. 3). Cardiomyopathy, neurological disorders, and liver dysfunction have been found in patients with defects in acyl-CoA dehydrogenase. ${ }^{67}$ Another mtDNA mutation, that of A3243G, which encodes tRNA (LeuUUR), has been shown to impair insulin secretion ${ }^{68}$ (Fig. 3). In addition, Hirschey et al. ${ }^{69}$ reported that SIRT3 deficiency and mitochondrial protein hyperacetylation accelerate the development of metabolic syndrome.

Moreover, type 2 diabetes, loss of weight, and reduced insulin secretion have been associated with the presence of polymorphisms in the promoter of UCP2. ${ }^{20,21}$ It has also been demonstrated that nuclear genes that encode mitochondrial proteins play an important role in insulin resistance. ${ }^{70}$ Thus, the pathogenesis of cardiometabolic syndrome and CVD, which occurs through functional impairment of mitochondria, is highly influenced by human genetic factors inherited through nuclear and/or mitochondrial genes. In addition, it is important to mention that the level of mitochondrial uncoupling is also an important determinant of mitochondria capacity.

\section{Oxidative Stress}

Mitochondria are the main source of ROS (Fig. 2), and these molecules are a fundamental factors in the development of diabetic complications. ${ }^{62,63,71}$ Therefore, the use of specific compounds to eradicate mitochondrial ROS has become important to ameliorate complications related with diabetes. ${ }^{72}$ For example, lipoic acid (LA) reduces inflammation and insulin resistance and improves mitochondrial function, thus, preventing CVD in humans. ${ }^{72}$

There are two main sites of electron leakage in the ETC: complex I and III. ${ }^{62,63,73,74}$ Excess production of ROS has an important effect on mitochondrial $\Delta \Psi_{\mathrm{m}}$ in diabetes, condition in which a high amount of substrates is supplied as a consequence of elevated levels of glucose. Specifically, it has been hypothesized that ETC dysfunction and its complications contribute to many diabetes-related pathologies, including nephropathy, neuropathy, and retinopathy, while deleterious genetic mutations involving a reduction in the activity of complex I lead to high rates of mitochondrial ROS production and mitochondrial impairment. ${ }^{75}$ This evidence highlights mitochondrial impairment as a research priority for the future. Indeed, mitochondria-targeted 
antioxidant therapy is already showing great promise in this respect. In fact, there are many enzymes in the mitochondria that are susceptible to damage by ROS, with complex I being the most vulnerable.

Mitochondrial dysfunction at complex I, together with an increment in ROS production, a reduction of $\Delta \Psi_{\mathrm{m}}$, and an impairment of antioxidant defenses ${ }^{11}$ have been described in diabetic patients. In other pathologies in which insulin resistance occurs, such as polycystic ovary syndrome (PCOS), impairment of mitochondrial complex I, and an increase in leukocyte-endothelium interactions have also been reported, ${ }^{76,77}$ while diabetic nephropathy is very common among patients with mitochondrial dysfunction. ${ }^{78}$ This damage eventually impairs the mitochondrial handling of calcium, alters $\Delta \Psi_{\mathrm{m}}$, and diminishes ATP production. In this sense, it has been described that CoQ10 can prevent the mitochondrial morphology and function, proteinuria and glomerular hyperfiltration in $\mathrm{db} / \mathrm{db}$ mice, highlighting the role of mitochondria in the pathogenesis of diabetic nephropathy. ${ }^{79}$

In a recent article, it has been also described that the increase in human leukocyte/endothelial cell interactions and mitochondrial dysfunction in type 2 diabetic patients correlate with the development of silent myocardial ischemia. ${ }^{80}$

Idebenone is a safe and efficient mitochondrial antioxidant that protects mitochondria from oxidative damage in Friedreich's ataxia patients. ${ }^{81}$ Interestingly, idebenone also reduces cardiomyopathy in the same subjects, unlike traditional antioxidants, such as $\alpha$-tocopherol or vitamin E. ${ }^{81,82}$ MitoQ, another mitochondria-targeted antioxidant, is selectively uptaken by mitochondria due to a covalent attachment to the lipophilic triphenylphosphonium $\left(\mathrm{TPP}^{+}\right)$cation, thus, accumulating 1000-fold in mitochondria. ${ }^{62,63,83}$ The efficacy of these mitochondriatargeted antioxidants in the treatment of cardiometabolic diseases and diabetes remains to be determined, but their targeted specificity for mitochondria is reason enough to study their potential as agents of diabetes and CVD therapy.

\section{INSULIN RESISTANCE AND MITOCHONDRIAL DYSFUNCTION}

Glucose homeostasis is mediated by insulin in a controlled relation with glucose uptake and gluconeogenesis rate. In addition, there are other less well-known roles of insulin associated with renal, cardiovascular, and neural functions, which may explain why insulin resistance is a risk factor for hypertension, CVD, neuropathy, retinopathy, and nephropathy. ${ }^{84}$

Insulin resistance is defined by a diminished capacity of tissues or cells to respond to the levels of insulin. Many conditions can contribute to this phenomenon, such as obesity, stress, environmental factors, or altered lipid and glucose metabolism. ${ }^{85}$ Indeed, the cellular and molecular mechanisms of insulin resistance are important to understanding the pathogenesis of several diseases with which it is associated.

Excess energy intake, lipodystrophy, or oxidative stress can increase circulating FFAs, which leads to accumulation of FFAs, triglycerides, and DG in different tissues, including skeletal muscle, liver, heart, and $\beta$-cells. In addition, the accumulation of lipids and a high-fat diet in mammals reduce insulin-stimulated glucose disposal. ${ }^{86}$ Considered together, these data suggest that alterations in lipid metabolism leading to impairment of insulin signaling are key to the development of insulin resistance. ${ }^{87,88}$ Moreover, the effects of impairment of insulin signaling can have a bearing on insulin-stimulated glucose metabolism in skeletal muscle and other tissues, such as heart, vasculature, liver, and adipose tissue. ${ }^{89,90}$

Insulin signaling constitutes a highly complex network composed of multiple pathways and signaling from heterologous receptors. ${ }^{91}$ It is initiated when insulin binds to insulin receptors (IRs), ${ }^{92}$ which causes an autophosphorylation of IR tyrosine residues and elevated tyrosine kinase activity of the receptor. Thus, the receptor can phosphorylate insulin receptor substrate 


\section{0 - ROCHA ET AL.}

(IRS) family members and can activate PI3K, leading to the generation of phosphatidylinositol 3,4,5-triphosphate. Activation of PI3K stimulates several downstream serine kinases, including protein kinase $\mathrm{B}(\mathrm{Akt})$, protein kinase $\mathrm{C}$ (PKC), phosphoinositide dependent kinase-1, and other kinases, all of which eventually modulate the biological and pleiotropic metabolic actions of insulin. Multiple mechanisms have been proposed for insulin resistance: ${ }^{92}$ (i) degradation of IRS proteins; ${ }^{93}$ (ii) elevated activity of phosphatases: ${ }^{94}$ (iii) increased serine phosphorylation of IRS proteins; ${ }^{95}$ and (iv) decreased activation of IR downstream signaling molecules including Akt and PKC. ${ }^{96}$

A decrease in tyrosine phosphorylation of IRS has been demonstrated in human subjects and in different insulin-resistant animal models. ${ }^{97,98}$ Phosphorylation of IRS proteins at specific serine residues can inhibit the interaction of said proteins with IR, leading to a decrease in tyrosine phosphorylation of IRS and undermining of the activation of PI3K. ${ }^{94}$ Increased proinflammatory signaling is other important mechanism of insulin resistance. In fact, FFAs can stimulate Toll-like receptors inducing proinflammatory signaling, which can activate $\mathrm{I} \kappa \mathrm{B}$ kinase $(\mathrm{IKK} \beta)$ and c-Jun $N$-terminal kinase (JNK), stimulating the production of proinflammatory cytokines, such as tumor necrosis factor- $\alpha$ (TNF- $\alpha$ ), interleukin- $\beta$, and interleukin- $6 .{ }^{99}, 100$ Studies with anti-inflammatory drugs or gene silencing of IKK $\beta$ or JNK have shown an improvement of insulin sensitivity, with significant reductions in serine phosphorylation of IRS proteins. ${ }^{101,102}$

Another important mechanism of insulin resistance based on activation of serine kinases is the endoplasmic reticulum (ER) stress. ER stress can activate JNK, thereby increasing serine phosphorylation of IRS proteins. In this sense, the use of chemical chaperones, such as 4-phenyl butyric acid (PBA) and taurine-conjugated ursodeoxycholic acids (TUDCAs), has therapeutic effects by improving insulin sensitivity and reducing ER stress. ${ }^{103}$ Such treatment has been shown to reduce hepatic JNK activity, IRS-1 serine phosphorylation, and fatty liver in animals. ${ }^{103}$ Therefore, ER stress appears to act both indirectly, by inducing lipid accumulation, and directly as a negative modulator of the insulin signaling pathway. For these reasons, ER stress is considered a key factor in the deyelopment of insulin resistance. ${ }^{104}$

One of the most plausible hypotheses concerning insulin resistance is that of mitochondrial dysfunction and consequent increases in ROS, which act as secondary messengers by activating the serine kinases that phosphorylate IRS proteins ${ }^{37}$ (Fig. 3). Furthermore, ROS can stimulate inflammatory signaling through activation of IKK $\beta$, which can phosphorylate IRS- $1 .{ }^{105}$ In this sense, mitochondrial function and insulin sensitivity have been demonstrated to improve by using antioxidants or following an increase in the expression of UCP2-UCP3 and a decrease in ROS levels. The increase of DG, FA metabolites, and long-chain fatty acyl-CoA can produce mitochondrial dysfunction. ${ }^{106}$ In this sense, DG, an allosteric activator of PKCs, can increase serine phosphorylation of IRS proteins, inducing insulin resistance. ${ }^{107} \mathrm{In}$ fact, $\mathrm{PKC} \theta$-deficient mice are protected against fat-induced insulin resistance. ${ }^{108}$ This suggests that the activation of PKCs as a result of mitochondrial dysfunction is another cause of insulin resistance.

Different studies of human biopsies, both in vivo and ex vivo, have highlighted the association of insulin resistance with impairment of mitochondrial function, including lower levels of mitochondrial oxidative enzymes, a decreased mitochondrial number, and abnormal mitochondrial morphology. ${ }^{109,110}$ In this sense, an increase in levels of plasma FFAs or lipids can induce insulin resistance in human liver and muscle. ${ }^{111}$ In diabetes, the accumulation of intramyocellular lipids leads to reducing mitochondrial oxidative capacity, which correlates negatively with insulin sensitivity. ${ }^{112}$

Obesity leads to an increase of triglycerides in adipose tissue, and consequently can alter glucose metabolism and insulin resistance in different nonadipose tissues. Conversely, it has been shown that lipodystrophy induces type 2 diabetes and insulin resistance in human subjects. ${ }^{113}$ Adipocytes can release adipokines, including leptin, adiponectin, resistin, and TNF- $\alpha$, which 
can modulate different metabolic pathways. ${ }^{114,115}$ In adipocytes from type 2 diabetic patients with obesity, the number of mitochondria and the expression of genes involved in mitochondrial biogenesis are significantly decreased. ${ }^{116}$ In this way, insulin-resistant metabolic tissue is characterized by a reduced mitochondrial gene expression in adipocytes, a lower number and abnormal morphology of mitochondria, and abnormal OXPHOS.

Endothelial dysfunction and insulin resistance are very common in CVD, such as coronary artery disease, heart failure, hypertension, silent myocardial ischemia, and stroke. ${ }^{117}$ In fact, high blood pressure is reported in over two-thirds of patients with type 2 diabetes, and its appearance coincides with hyperglycemia. ${ }^{118}$ Increased levels of FFAs can contribute to insulin resistance by reducing mitochondrial oxidative capacity, ATP synthesis, and cardiac efficiency in insulin-resistant $o b / o b$ and obese mice. ${ }^{119}$ In addition, intramyocardial lipid accumulation can induce lipotoxic injury and cardiac dysfunction in different mouse models of obesity.120, 121 The impairment of endothelium-dependent vasodilation and glucose intolerance can be related to intramyocardial lipid accumulation, and this effect can precede type 2 diabetes and heart failure. ${ }^{122}$

The heart, one of the tissues with the greatest caloric needs and most robust oxidation of FAs, contains low levels of endogenous antioxidants, which makes it particularly susceptible to oxidative stress and subsequent functional and structural abnormalities. ${ }^{123}$ An association has been demonstrated between alterations of mitochondrial morphology/function and mitochondrial oxidative state in the myocardium of Zucker obese rats with insulin resistance. ${ }^{124}$ Transmission electron microscopic analysis of myocardial tissue has revealed increased numbers of morphologically abnormal mitochondria in several insulin-resistant rat models. ${ }^{125}$ Similarly, an increase in the number of mitochondria has been recorded in hypertrophied rat hearts displaying oxidative stress, ${ }^{126}$ perhaps as a consequence of the energy requirements and of ROS production. In contrast, other studies have demonstrated that the number of mitochondria and their DNA content are reduced in animal models of pathological hypertrophy and patients. ${ }^{127}$ In summary, the role of mitochondria in the heart is essential, and cardiac mitochondrial dysfunction seems to contribute to CVD, including cardiomyopathy, coronary heart disease, heart failure, hypertension, and silent myocardial ischemia.

An interaction between endothelial dysfunction and insulin resistance has been proposed, ${ }^{128}$ though the details are still unclear. Endothelial cells are glycolitic cells. ${ }^{129}$ Moreover, mitochondria in the endothelium can play a relevant role as sensors for local $\mathrm{O}_{2}$ concentration and in signaling as regulators of intracellular $\left[\mathrm{Ca}^{2+}\right] \cdot{ }^{130} \mathrm{In}$ addition, it has been proposed that mitochondrial dysfunction and subsequent ROS production are the key factors in the development of macrovascular and microvascular damage. ${ }^{8}$ Different studies have shown that it is possible to prevent the endothelial dysfunction associated with hyperglycemia by blocking the excess of mitochondrial ROS generation. ${ }^{131,132}$

In addition, endothelial nitric oxide synthase (eNOS) in vessels can play an important role in vasodilation, mitochondrial biogenesis, and insulin-stimulated NO production. ${ }^{133}$ Indeed, eNOS knockout mice are characterized by dyslipidemia, hypertension, and insulin resistance. ${ }^{134}$ Thus, insulin resistance impairs NO synthesis and the mitochondrial dysfunction associated with it compromises several cardiac functions, which in turn leads to heart failure, coronary artery disease, and silent myocardial ischemia (Fig. 3).

Type 2 diabetes can appear in insulin-resistant patients when $\beta$-cells cannot sense glucose properly and fail to produce and secrete enough insulin to maintain normal levels of glucose. Mitochondrial function increases the ATP:ADP ratio and can modulate the inhibition of the potassium channel $\left(\mathrm{K}_{\mathrm{ATP}}\right)$, which leads to secretion of insulin. In addition, mitochondrial function is related with $\beta$-cell function through the ATP:ADP ratio. ${ }^{135}$ Han et al. have shown that taurine can enhance the glucose sensitivity of UCP2 overexpressing $\beta$-cells probably by 
12 - ROCHA ET AL.

enhancing mitochondrial $\mathrm{Ca}^{2+}$ influx through the $\mathrm{Ca}^{2+}$ transporter, which enhances mitochondrial function and increases the ATP/ADP ratio as a result. ${ }^{136}$ In addition, it has been demonstrated that insulin secretion is impaired in $\beta$-cells which are deficient in some mitochondrial genes, and that when this situation is reversed, $\beta$-cells recover their capacity to secrete insulin. ${ }^{137}$ Knockout of Tfam, a nuclear DNA-encoded mitochondrial protein, results in impaired insulin secretion, reduced $\beta$-cell mass, severe mtDNA depletion, and development of diabetes. ${ }^{138}$ The results of these studies support the hypothesis that mitochondrial function is important for $\beta$-cell function and contributes to the pathogenesis of type 2 diabetes by modulating insulin secretion and insulin action. Thus, lipid-induced mitochondrial dysfunction can impair insulin signaling due to the generation of ROS. For all these reasons, mitochondria should be considered a key target in therapy for insulin resistance and related diseases.

\section{STRATEGIES FOR MITOCHONDRIAL PHARMACOLOGY WITH SPECIAL FOCUS ON ANTIOXIDANTS}

The delivery of drugs to specific subcellular compartments improves the therapeutic efficacy of the compounds and avoids the detrimental consequences of their accumulation in off-target subcellular territories. Mitochondrial drug targeting, a process of selective drug delivery to these organelles, is a complex action that depends on the presence (or more often lack) of specific transporters on the mitochondrial membrane. As it is particularly difficult to diffuse through the inner membrane, mitochondria-targeted molecules need to be encapsulated inside a carrier, a process which needs to guarantee the preservation and the control of the drug's pharmacological activity once the active molecule is inside the mitochondrion. Current strategies for delivering drugs to the mitochondria fall into two categories: active and passive targeting. ${ }^{139}$ In the former case, specific interactions are provoked at mitochondrial sites, including antigen-antibody and ligand-receptor association, and in the latter, the physicochemical properties (electric charge, hydrophilicity, size, and mass) of the carrier are compatible with those of the mitochondrial compartment, thus, converting mitochondria into a specific pharmacological target. Small molecules have been successfully targeted to mitochondria in vivo in several ways; namely, through conjugation to lipophilic cations, ${ }^{140}$ enclosure inside liposomes, ${ }^{139}$ and incorporation into mitochondria-targeted peptides ${ }^{141}$ (Fig. 4). To date, the molecules used in these targeting approaches involve coenzymes and substrates of the ETC, such as cytochrome $c$; succinate vitamin $\mathrm{B} 1, \mathrm{~B} 2$; and proapoptotic proteins, such as the Bax/Bcl2 family and $\mathrm{p} 53$, as well as relevant antioxidants. ${ }^{139}$

Mitochondrial $\Delta \Psi_{\mathrm{m}}$ is used by lipophilic cations for their selective accumulation within the mitochondrial matrix (Fig. 4) ${ }^{142}$ This process is expressed by the Nernst equation, by which uptake increases tenfold for every $60 \mathrm{mV}$ of plasma membrane potential, leading to uptake within mitochondria in vivo. ${ }^{143,144}$ The use of lipophilic cations to deliver pharmacological agents to the cell interior was first demonstrated with the lipophilic cation rhodamine 123 in a complex with the anticancer compound cisplatin. ${ }^{145} \mathrm{TPP}^{+}$and its methylated form $\mathrm{TPMP}^{+}$are the most widely used lipophilic cations for mitochondrial accumulation of antioxidants. ${ }^{140} \mathrm{An}$ alternative spin trap with a lower molecular weight and bearing an $N$-arylpyridinium ion ${ }^{146}$ has been employed with seemingly positive results, though its efficacy requires further confirmation. The TPP moiety, driven by the plasma membrane potential allows rapid cellular uptake of bioactive molecules, followed by specific mitochondrial matrix accumulation. A high number of antioxidants have been successfully targeted to mitochondria through their conjugation to TPP, including ubiquinone; ${ }^{147,148}$ vitamin $\mathrm{E} ;{ }^{149}$ resveratrol; ${ }^{150}$ ebselen; $;{ }^{151}$ LA $;{ }^{152}$ nitroxides, 


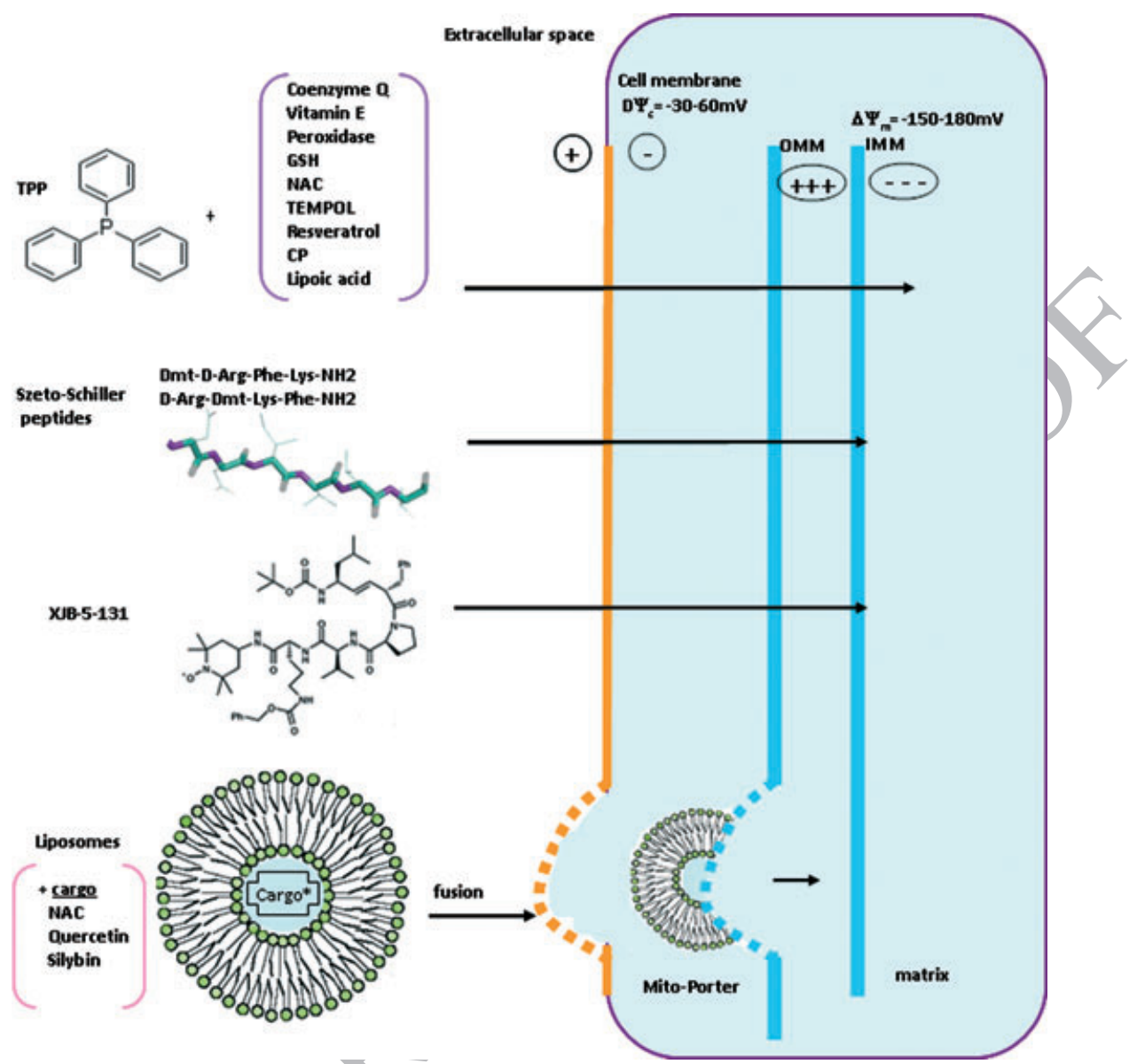

Figure 4. Mitochondrial delivery systems. A Lipophilic cations, such as TPP specifically enter mitochondria in a $\Delta \Psi_{\mathrm{m}}$-dependent fashion. TPP has been conjugated with several antioxidants exemplified by vitamin $\mathrm{E}$ (mitoE) and coenzyme Q (MitoQ). B Szeto-Schiller peptides are cationic agents that localize mainly to the IMM (80\%). Their antioxidant properties lie in the presence of tyrosine and dimethyltyrosine residues. C XJB-5-131 is targeted to the mitochondrion through its oligopeptidic fragment of the membrane-active antibiotic gramicidin S. A stable nitroxide radical portion of this compound renders it antioxidant. D Antioxidant liposomes carry lipid- or watersoluble cargo of antioxidants. A special type of liposome-based carrier is MITO-Porter, a mitochondria-targeted envelope-type nanodevice that delivers its cargo to the target compartment through fusion. Dmt, dimethyltyrosine; GSH, glutathione; IMM, inner mitochondrial membrane; NAC, N-acetyl cysteine; OMM, outer mitochondrial membrane; TEMPOL, 4-hidroxy-2,2,6,6-tetramethylpiperidine-1-oxy radical; TPP, triphenylphosphonium.

such as TEMPOL, ${ }^{153}$ plastoquinone, ${ }^{154}$ and nitrones (Fig. 4). ${ }^{155}$ Lipophilic cations show great potential with respect to the accurate delivery of antioxidants to mitochondria; however, they have the following disadvantages: (i) their capacity (only electrically neutral and low molecular weight molecules can be successfully transferred); (ii) their sublocalization (these chemicals tend to localize to the mitochondrial matrix and the matrix-facing surface of the inner membrane, disabling the targeting of many important processes that take place on the outer surface of the inner membrane, the outer membrane, or the intermembrane space); and (iii) their toxicity (at high concentrations they can depolarize $\Delta \Psi_{\mathrm{m}}$ and compromise cell viability).

MitoQ, which consists of a ubiquinone moiety linked to a TPP by a ten-carbon alkyl chain, is the most studied and widely used mitochondrial antioxidant. ${ }^{140}$ Within mitochondria, MitoQ is adsorbed to the matrix-facing surface of the inner mitochondrial membrane (IMM), 


\section{4 - ROCHA ET AL.}

where it can be recycled by complex II of the ETC into the active ubiquinol form. ${ }^{149,156}$ This highly effective antioxidant reacts with ROS, such as peroxynitrite $\left(\mathrm{ONOO}^{-}\right)$, and also inhibits its formation ${ }^{149}$ and mitochondrial lipid peroxidation. ${ }^{156,157}$ In addition, the ubiquinone form is known to react directly with other ROS, such as superoxide. ${ }^{158}$ MitoQ has been shown to have a beneficial role in several in vitro settings of mitochondrial oxidative stress. More importantly, its benefits have been reported in animal models of cardiometabolic pathologies, such as ischemia/reperfusion, sepsis, and diabetes (Table I), and in humans. ${ }^{159}$ Of note, it has been demonstrated that intravenous and oral administration of MitoQ leads to a rapid uptake from blood into cells. ${ }^{143} \mathrm{~A}$ growing number of studies confirms that antioxidants are capable of modulating mitochondrial survival/cell-death pathways, including apoptosis, mitophagy, mitoptosis, and necrosis. In this regard, mitochondria-targeted antioxidants merit a special attention. It has been demonstrated that MitoQ inhibits the mitochondrial fission induced in HeLa cells and fibroblasts by mitochondrial respiratory chain inhibitors (piericidin and myxothiazol), which points to the beneficial potential of MitoQ in novel mitochondrial contexts, such as mitochondrial dynamics. ${ }^{160}$

Although the therapeutic efficacy of mitochondria-targeted antioxidants in diabetes or CVD needs to be confirmed, several in vivo and in vitro studies have demonstrated their useful effects (Table I). In one study, mitochondria-targeted antioxidants were employed in $\beta$-cells such as RINm5F and HIT-T15 under conditions of glucolipotoxic and glucotoxic stress typical of type 2 diabetes. ${ }^{161}$ Results in $\beta$-cells under oxidative stress conditions showed an increase in the levels of mitochondrial antioxidant enzymes (such as MnSOD), the expression of mitochondrial ETC complex subunits and lipogenic enzymes (such as ATP-binding cassette transporter A1 [ABCA1]), FA synthase (FAS), and acetyl-CoA carboxylase (ACC), as well as induction of apoptosis, intracellular lipid droplet accumulation, presence of oxidative stress and ER stress, mitochondrial membrane depolarization, expression of sterol regulatory element binding protein 1c (SREBP1c), and NF- $\kappa$ B, together with a decrease in citrate synthase activity, ATP concentration, and insulin release. These changes were related with mitochondrial oxidative stress and were prevented by the mitochondria-targeted antioxidants MitoQ or Mito Tempol, which protected $\beta$-cells, thereby improving insulin secretion and the survival of said cells. The protective effects of complications associated with diabetes, such as diabetic nephropathy and retinopathy. Li et al. described a beneficial effect of peptide SS31, a mitochondria-targeted antioxidant, on hyperglycemia-induced damage in human retinal endothelial cells (HRECs). ${ }^{162}$ They reported that exposure to SS31 decreased mitochondrial ROS production, diminished the release of cytochrome $c$ from the mitochondrion to the cytosol, stabilized $\Delta \Psi_{\mathrm{m}}$, decreased the expression of caspase-3, and enhanced the expression of Trx-2 in HRECs. Mitochondriatargeted antioxidants have demonstrated their potential therapeutic effect in models of tolerance to nitroglycerine $(\mathrm{GTN})$ in cardiometabolic diseases. In different studies of nitrate tolerance, the effects of GTN on mitochondrial $\mathrm{O}_{2}$ consumption and ALDH-2 activity were shown to be prevented by MitoQ. ${ }^{163,164}$

There is also in vivo evidence for the beneficial effects of MitoQ in cardiometabolic pathologies. Chacko et al. demonstrated that, when administered orally over a 12-week period, MitoQ improved glomerular and tubular function in an animal model of diabetes type 1 , Ins $2\left(^{+/-}\right.$) (AkitaJ) mice. ${ }^{165}$ MitoQ did not significantly change creatinine levels, but reduced urinary albumin to levels similar to those exhibited by nondiabetic animals. In addition, MitoQ prevented the increased nuclear accumulation of the pro-fibrotic transcription factors phospho-Smad $2 / 3$ and $\beta$-catenin.

The beneficial effects of MitoQ have been reported in animal models of metabolic syndrome and atherosclerosis (fat-fed $\mathrm{ApoE}^{-/-}$and $\mathrm{ATM}^{+/-} / \mathrm{ApoE}^{-/-}$mice, which are haploinsufficient for ataxia telangiectasia mutated protein kinase, ATM). This antioxidant prevented 
Table I. Mitochondria-Targeted Antioxidants which Have Shown Protective Effects in In Vivo (Animal) and/or In Vitro (Cell) Models of Cardiometabolic Pathologies

\begin{tabular}{llc}
\hline Compound & \multicolumn{1}{c}{ Cardiometabolic condition } & References $^{\mathrm{a}}$ \\
\hline MitoQ & Cardiac I/R injury & {$[1,2]$} \\
& Endothelial nitroglycerin tolerance & {$[3]$} \\
& Hypertension with cardiac hypertrophy & {$[4]$} \\
& Kidney damage in type 1 diabetes & {$[5]$} \\
& Oxidative damage of beta cells & {$[6]$} \\
& Atherosclerosis and the metabolic syndrome & {$[7]$} \\
& Obesity & {$[8]$} \\
& Coronary artery disease with diabetes & {$[9]$} \\
SS31 & Cardiac I/R injury & {$[10]$} \\
& Hypertensive cardiomyopathy & {$[11]$} \\
& Insulin resistance & {$[12]$} \\
MitoTEMPO & Diabetic retinopathy & {$[13]$} \\
SkQ1 & Hypertension & {$[14]$} \\
& Oxidative damage of beta cells & {$[6]$} \\
& Cardiac I/R injury & {$[15]$} \\
\hline
\end{tabular}

aReferences:

1. Adlam VJ, Harrison JC, Porteous CM, James AM, Smith RA, Murphy MP, Sammut IA. Targeting an antioxidant to mitochondria decreases cardiac ischemia-reperfusion injury. FASEB $J$ 2005; 19(9): 1088-1095.

2. Neuzil J, Widén C, Gellert N, Swettenham E, Zobalova R, Dong LF, Wang XF, Lidebjer C, Dalen H, Headrick JP, Witting PK. Mitochondria transmit apoptosis signalling in cardiomyocyte-like cells and isolated hearts exposed to experimental ischemia-reperfusion injury. Redox Rep 2007;12(3):148162.

3. Esplugues JV, Rocha M, Nuñez C, Boscà I, Ibiza S, Herance JR, Ortega A, Serrador JM, D'Ocon P, Victor VM. Complex I dysfunction and tolerance to nitroglycerin: an approach based on mitochondrial-targeted antioxidants. Circ Res 2006;99(10):1067-1075.

4. Graham D, Huynh NN, Hamilton CA, Beattie E, Smith RA, Cochemé HM, Murphy MP, Dominiczak AF. Mitochondria-targeted antioxidant MitoQ10 improves endothelial function and attenuates cardiac hypertrophy. Hypertension 2009 Aug;54(2):322-328.

5. Chacko BK, Reily C, Srivastava A, Johnson MS, Ye Y, Ulasova E, Agarwal A, Zinn KR, Murphy MP, Kalyanaraman B, Darley-Usmar V. Prevention of diabetic nephropathy in Ins2(+//) ${ }^{-}$(AkitaJ) mice by the mitochondria-targeted therapy MitoQ. Biochem J 2010;432(1):9-19.

6. Lim S, Rashid MA, Jang M, Kim Y, Won H, Lee J, Woo JT, Kim YS, Murphy MP, Ali L, Ha J, Kim SS. Mitochondria-targeted antioxidants protect pancreatic $\beta$-cells against oxidative stress and improve insulin secretion in glucotoxicity and glucolipotoxicity. Cell Physiol Biochem 2011;28(5):873-886.

7. Mercer JR, Yu E, Figg N, Cheng KK, Prime TA, Griffin JL, Masoodi M, Vidal-Puig A, Murphy MP, Bennett MR. The mitochondria-targeted antioxidant MitoQ decreases features of the metabolic syndrome in ATM+/-/ApoE-/- mice. Free Radic Biol Med. 2012 Mar 1;52(5):841-849.

8. Pung YF, Rocic P, Murphy MP, Smith RA, Hafemeister J, Ohanyan V, Guarini G, Yin L, Chilian WM. Resolution of mitochondrial oxidative stress rescues coronary collateral growth in Zucker obese fatty rats. Arterioscler Thromb Vasc Biol. 2012 Feb;32(2):325-334.

9. Mackenzie RM, Salt IP, Miller WH, Logan A, Ibrahim HA, Degasperi A, Dymott JA, Hamilton CA, Murphy MP, Delles C, Dominiczak AF. Mitochondrial reactive oxygen species enhance AMPK activation in the endothelium of patients with coronary artery disease and diabetes. Clin Sci (Lond) 2012.

10. Zhao K, Zhao GM, Wu D, Soong Y, Birk AV, Schiller PW, Szeto HH. Cell-permeable peptide antioxidants targeted to inner mitochondrial membrane inhibit mitochondrial swelling, oxidative cell death, and reperfusion injury. Biol Chem. 2004;279(33):34682-34690. 
16 - ROCHA ET AL.

Table I. Continued

11. Dai DF, Chen T, Szeto H, Nieves-Cintrón M, Kutyavin V, Santana LF, Rabinovitch PS. Mitochondrial targeted antioxidant peptide ameliorates hypertensive cardiomyopathy. J Am Coll Cardiol 2011;58(1):73-82.

12. Anderson EJ, Lustig ME, Boyle KE, Woodlief TL, Kane DA, Lin CT, Price JW 3rd, Kang L, Rabinovitch PS, Szeto HH, Houmard JA, Cortright RN, Wasserman DH, Neufer PD. Mitochondrial $\mathrm{H}_{2} \mathrm{O}_{2}$ emission and cellular redox state link excess fat intake to insulin resistance in both rodents and humans. J Clin Invest 2009;119(3):573-581.

13. Li J, Chen X, Xiao W, Ma W, Li T, Huang J, Liu X, Liang X, Tang S, Luo Y. Mitochondria-targeted antioxidant peptide SS31 attenuates high glucose-induced injury on human retinal endothelial cells. Biochem Biophys Res Commun 2011;404(1):349-356.

14. Dikalova AE, Bikineyeva AT, Budzyn K, Nazarewicz RR, McCann L, Lewis W, Harrison DG, Dikalov SI. Therapeutic targeting of mitochondrial superoxide in hypertension. Circ Res 2010,107(1):106116.

15. Lakomkin VL, Kapel'ko VI. Protective effect of mitochondrial antioxidant SkQI at cardiac ischemia and reperfusion. Kardiologiia 2009;49(10):55-60.

hypercholesterolemia, the increase in adiposity, and hypertriglyceridemia related to metabolic syndrome, when administered orally for 14 weeks. It also reduced hepatic steatosis, hyperglycemia, and lipid and DNA oxidative damage (8-oxo-G) in different organs. Furthermore, a lower macrophage content and diminished cell proliferation were observed within the plaques of fat-fed $\mathrm{ATM}^{+/-} / \mathrm{ApoE}^{-/-}$and $\mathrm{ATM}^{+/} / / \mathrm{ApoE}^{-1-}$ mice after administration of MitoQ, although the overall atherosclerotic plaque area was not modified. ${ }^{166}$

Another recently published study has demonstrated a beneficial role of mitochondriatargeted antioxidants in obesity-related comorbidities. Zucker obese fatty (ZOF) rats have high levels of ROS in smooth muscle cells and the aortic endothelium and display increased UCP2 and antioxidant enzyme activity in comparison with Zucker control rats. MitoQ significantly reduced lipid peroxides in $\mathrm{ZOF}$ rats to levels similar to those seen in lean rats and improved the metabolic profiles. This beneficial effect restored coronary collateral growth in response to repetitive ischemia to the level of the control animals. ${ }^{167}$

Liposomal carriers are constituted by phosphatidylcholine, phosphatidylglycerol, and cholesterol, which can inclose small molecular weight antioxidants, antioxidants enzymes, or a combination of various agents with antioxidant activities. ${ }^{168}$ It appears that antioxidants, such as the liposomally encapsulated $N$-acetylcysteine ${ }^{169}$, quercetin, and Siliphos (a complex formed by silybin and phospholipids), have therapeutic effects (Fig. 4). Siliphos has been shown to be hepatoprotective in a rat model of steatosis ${ }^{170}$ and to ameliorate liver enzyme levels in NAFLD patients ${ }^{171}$ by enhancing mitochondrial function and through an insulin-sensitizing action.

MITO-Porter is a liposome-based nanocarrier that delivers cargo to mitochondria through a membrane fusion mechanism (Fig. 4) based on the multifunctional envelope-type nanodevice (MEND), which consists of a condensed plasmidic DNA core and a lipid envelope that mimics envelope-type viruses. ${ }^{172}$ This mechanism seems to be capable of transporting functional nucleic acids, proteins, and small bioactive molecules. ${ }^{173}$ These delivery systems are useful as they can transport encapsulated molecules of varying physicochemical characteristics or size. Mitochondrial delivery using MITO-Porter takes place in three steps: (i) delivery of the carrier from the extracellular space to the cytosol; (ii) intracellular trafficking of the carrier, including mitochondrial targeting; and (iii) mitochondrial delivery via membrane fusion. Also, a conjugate nanocarrier that targets mitochondria and contains a mitochondria-targeting signal peptide (MTS) and MITO-Porter has been developed very recently. ${ }^{174}$ 
Szeto-Schiller (SS)-peptides ${ }^{175}$ and mitochondria-penetrating peptides (MPPs) ${ }^{176}$ are peptide-based targeting ways of delivering antioxidants to mitochondria. SS-peptides are antioxidant compounds with three positive charges in homeostatic $\mathrm{pH}$ conditions. In vitro cell studies have shown their rapid uptake through the cellular membrane in a concentrationdependent way by which they accumulate 1000 -fold in mitochondria where they bind to the IMM through a mechanism that is not completely described. ${ }^{177,178}$ It is important to mention that the particular mitochondrial uptake of these compounds does not take place in response to $\Delta \Psi_{\mathrm{m}}, 177,179$ this is advantageous, as mitochondrial membrane polarization is not disturbed and that the process is not self-limiting. SS-peptides have been shown to exert a protective effect against oxidative stress in cellular models of disease, including insulin resistance, and in isolated mitochondria (Table I), with SS-31 demonstrating to be the most beneficial. ${ }^{175,180,181}$ In terms of the increase of MPPs in the mitochondrial matrix, hydrophobicity and electric charge seem to be of great relevance, ${ }^{182}$ although the mechanisms by which MPPs are transported through the phospholipid bilayer and the role of $\Delta \Psi_{\mathrm{m}}$ are unclear.

Novel mitochondria-targeted molecules and their therapeutic potential have recently been described. XJB-5-131 is an electron and ROS scavenger containing the Leu-D-Phe-Pro-Val-Orn fragment of gramicidin S, a membrane-active cyclopeptide antibiotic. ${ }^{183}$ (Fig. 4). Due to the high affinity of this type of antibiotics for bacterial membranes, which resemble mitochondrial membranes, XJB-5-131 can be targeted successfully to the mitochondrion. This compound has been shown to be beneficial in acute tissue ischemia, such as that produced in rat enterocytes exposed to lethal hemorrhagic shock. ${ }^{184}$

Another approach to targeting bioactive molecules to the mitochondrial matrix is platform technology using biodegradable polymers. ${ }^{185}$ This method involves a rationally designed mitochondria-targeted polymeric nanoparticle (NP) system and the combination of a targeted poly(D,L-lactic-co-glycolic acid)-block (PLGA-b)-poly(ethylene glycol) (PEG)- TPP polymer (PLGA-b-PEG-TPP) with either nontargeted PLGA-b-PEG-OH or PLGA-COOH. In particular, the construct PLGA-b-PEG-TPP NP shows great promise as a component of therapy for mitochondrial dysfunction-related metabolic diseases, such as obesity.

\section{A. Summary and Perspectives}

Oxidative stress is clearly related to the pathogenesis of cardiometabolic diseases, while the pathophysiological importance of different molecules requires further study. In general, the data obtained with antioxidant strategies employed to limit the pathophysiological effects of insulin resistance are scarce and inconsistent. Mitochondria play a critical role in cardiometabolic diseases, such as metabolic syndrome and diabetes. The level of mitochondrial ATP is crucial in regulating insulin release; mitochondrial ROS, which otherwise exerts a vital role as secondary messengers, impair this process. Mitochondrial function is a key factor in insulin sensitivity in tissues, such as muscle, liver, and adipose tissue. In this review, we have focused on the mechanisms of the mitochondrial dysfunction related with the pathophysiology of insulin resistance and type 2 diabetes in different tissues, and have considered the process of cardiometabolic diseases from a mitochondrial perspective. We have discussed the potential beneficial effects of mitochondria-targeted antioxidants as a tool for modulating mitochondrial function in cardiometabolic diseases, and particularly in diabetes. The future of mitochondrial pharmacology will depend on the development of mitochondria-targeted antioxidants and new and accurate methods of assessing all aspects of mitochondrial function in patients. To conclude, we believe that mitochondrial pharmacology has great potential as an emerging therapeutic element to be used in many aspects of medicine. 
We thank B. Normanly for his editorial assistance. This study was financed by grants PI10/1195, PI 12/1982, CIBERehd CB06/04/0071, PROMETEO 2010/060, ACOMP/2012/042, ACOMP/2012/045, and by the European Regional Development Fund (ERDF). V.M.V. and M.R. are recipients of contracts from the Ministry of Health of the Valencian Regional Government and Carlos III Health Institute (CES10/030 and CP10/0360, respectively). N.A. is beneficiary of a Juan de la Cierva contract (JCI-2011-11357, Ministerio de Ciencia e Innovación). S.R. is recipient of a predoctoral fellowship from Carlos III Health Institute (FI11/00637).

No potential conflicts of interest relevant to this article are reported. The authors have nothing to disclose.

\section{REFERENCES}

1. Popkin BM. Global nutrition dynamics: The world is shifting rapidly toward a diet linked with noncommunicable diseases. Am J Clin Nutr 2006;84:289-298.

2. Smith SC. Multiple risk factors for cardiovascular disease and diabetes mellitus. Am J Med 2007;120:3-11.

3. Cooper SA, Whaley-Connell A, Habibi J, Wei Y, Lastra G, Manrique C, Stas S, Sowers JR. Renin-angiotensin-aldosterone system and oxidative stress in cardiovascular insulin resistance. Am J Physiol Heart Circ Physiol 2007;293:2009-2023.

4. Reaven GM, Chen YD. Insulin resistance, its consequences, and coronary heart disease. Must we choose one culprit? Circulation 1996;93:1780-1783.

5. Brehm A, Krssak M, Schmid AI, Nowotny P, Waldhausl W, Roden M. Increased lipid availability impairs insulin-stimulated ATP synthesis in human skeletal muscle. Diabetes 2006;55:136-140.

6. Ritz P, Berrut G. Mitochondrial function, energy expenditure, aging and insulin resistance. Diabetes Metab 2005;31:5S67-5S73.

7. Frisard M, Ravussin E. Energy metabolism and oxidative stress: Impact on the metabolic syndrome and the aging process. Endocrine 2006;29:27-32.

8. Brownlee M. The pathobiology of diabetic complications: A unifying mechanism. Diabetes 2005;54:1615-1625.

9. Befroy DE, Petersen KF, Dufour S, Mason GF, de Graaf RA, Rothman DL, Shulman GI. Impaired mitochondrial substrate oxidation in muscle of insulin-resistant offspring of type 2 diabetic patients. Diabetés 2007;56:1376-1381.

10. Ashrafian H, Frenneaux MP, Opie LH. Metabolic mechanisms in heart failure. Circulation 2007;116:434-448.

11. Hernandez-Mijares A, Rocha M, Apostolova N, Borras C, Jover A, Bañuls C, Sola E, Victor VM. Mitochondrial complex I impairment in leukocytes from type 2 diabetic patients. Free Radic Biol Med 2011;50:1215-1221.

12. Marín-García J, Akhmedov AT, Moe GW. Mitochondria in heart failure: The emerging role of mitochondrial dynamics. Heart Fail Rev 2012.

13. Chen AF, Chen DD, Daiber A, Faraci FM, Li H, Rembold CM, Laher I. Free radical biology of the cardiovascular system. Clin Sci (Lond) 2012;123:73-91.

14. Tocchetti CG, Caceres V, Stanley BA, Xie C, Shi S, Watson WH, O'Rourke B, SpadariBratfisch RC, Cortassa S, Akar FG, Paolocci N, Aon MA. GSH or palmitate preserves mitochondrial energetic/redox balance, preventing mechanical dysfunction in metabolically challenged myocytes/hearts from type 2 diabetic mice. Diabetes 2012;61:3094-3105.

15. Harper ME, Bevilacqua L, Hagopian K, Weindruch R, Ramsey JJ. Ageing, oxidative stress, and mitochondrial uncoupling. Acta Physiol Scand 2004;182:321-331. 
16. Mailloux RJ, Harper ME. Uncoupling proteins and the control of mitochondrial reactive oxygen species production. Free Radic Biol Med 2011;51:1106-1115.

17. Arsenijevic D, Onuma H, Pecqueur C, Raimbault S, Manning BS, Miroux B, Couplan E, AlvesGuerra MC, Goubern M, Surwit R, Bouillaud F, Richard D, Collins S, Ricquier D. Disruption of the uncoupling protein-2 gene in mice reveals a role in immunity and reactive oxygen species production. Nat Genet 2000;26:435-439.

18. Lee KU, Lee IK, Han J, Song DK, Kim YM, Song HS, Kim HS, Lee WJ, Koh EH, Song KH, Han SM, Kim MS, Park IS, Park JY. Effects of recombinant adenovirus-mediated uncoupling protein 2 overexpression on endothelial function and apoptosis. Circ Res 2005;96:12001207.

19. Clapham JC, Arch JR, Chapman H, Haynes A, Lister C, Moore GB, Piercy V, Carter SA, Lehner I, Smith SA, Beeley LJ, Godden RJ, Herrity N, Skehel M, Changani KK, Hockings PD, Reid DG, Squires SM, Hatcher J, Trail B, Latcham J, Rastan S, Harper AJ, Cadenas S, Buckingham JA, Brand MD, Abuin A. Mice overexpressing human uncoupling protein-3 in skeletal muscle are hyperphagic and lean. Nature 2000;406:415-418.

20. Sesti G, Cardellini M, Marini MA, Frontoni S, D'Adamo M, Del Guerra S, Lauro D, De Nicholais P, Sbraccia P, Del Parto S, Gambardella S, Federici M, Marchetti P, Lauro R, A common polymorphism in the promoter of UCP2 contributes to the variation in insulin secretion in glucose-tolerant subjects. Diabetes 2003;52:1280-1283.

21. Beitelshees AL, Finck BN, Leone TC, Cresci S, Wu J, Province MA, Fabbrini E, Kirk E, Zineh I, Klein S, Spertus JA, Kelly DP. Interaction between the UCP2-866 G > A polymorphism, diabetes, and beta-blocker use among patients with acute coronary syndromes. Pharmacogenet Genomics 2010;20:231-238.

22. Murray AJ, Anderson RE, Watson GC, Radda GK, Clarke K. Uncoupling proteins in human heart. Lancet 2004;364:1786-1788.

23. Hesselink MK, Mensink M, Schrauwen P. Human uncoupling protein-3 and obesity: An update. Obes Res 2003;11:1429-1443.

24. Schrauwen $\mathrm{P}$, Hesselink MK. The role of uncoupling protein 3 in fatty acid metabolism: Protection against lipotoxicity? Proc Nutr Soc 2004;63:287-292.

25. Hesselink MK, Schrauwen P. Uncoupling proteins in the failing human heart: Friend or foe?. Lancet 2005;365:385-386.

26. Hoeks J, Hesselink MK, van Bilsen M, Schaart G, van der Vusse GJ, Saris WH, Schrauwen P. Differential response of UCP3 to medium versus long chain triacylglycerols; manifestation of a functional adaptation. FEBS Lett 2003;555:631-637.

27. Laurent D, Yerby B, Deacon R, Gao J. Diet-induced modulation of mitochondrial activity in rat muscle. Am J Physiol Endocrinol Metab 2007;293:E1169-E1177.

28. Sparks L, Xie H, Koza R, Mynatt R, Hulver M, Bray G, Smith S. A high-fat diet coordinately downregulates genes required for mitochondrial oxidative phosphorylation in skeletal muscle. Diabetes 2005;54:1926-1933.

29. Erion DM, Shulman GI. Diacylglycerol-mediated insulin resistance. Nat Med 2010;16:400-402.

30. Forman B, Chen J, Evans R. Hypolipidemic drugs, polyunsaturated fatty acids and eicosanoids are ligands for peroxisome-proliferator activated receptors $\alpha$ and $\delta$. Proc Natl Acad Sci USA 1997;94:4312-4317.

31. Aubert J, Champigny O, Saint-Marc P, Negrel R, Collins S, Ricquier D, Aihaud G. Upregulation of UCP2 gene expression by PPAR agonists in preadipose and adipose cells. Biochem Biophys Res Commun 1997;238:606-611.

32. Bugge A, Siersbæk M, Madsen M, Göndör A, Rougier C, Mandrup S. A novel intronic peroxisomeproliferator activated receptor $\gamma$ enhancer in the uncoupling protein (UCP) 3 gene as a regulator of both UCP2 and 3 expression in adipocytes. J Biol Chem 2010;285:17310-17317.

33. Hurtaud C, Gelly C, Chen Z, Lévi-Meyrueis C, Bouillaud F.Glutamine stimulates translation of uncoupling protein 2 mRNA. Cell Mol Life Sci 2007;64:1853-1860. 
34. Stump CS, Short KR, Bigelow ML, Schimke JM, Nair KS. Effect of insulin on human skeletal muscle mitochondrial ATP production, protein synthesis, and mRNA transcripts. Proc Natl Acad Sci USA 2003;100:7996-8001.

35. Petersen KF, Befroy D, Dufour S, Dziura J, Ariyan C, Rothman DL, DiPietro L, Cline GW, Shulman GI. Mitochondrial dysfunction in the elderly: Possible role in insulin resistance. Science 2003;300:1140-1142.

36. van Tienen FH, Praet SF, de Feyter HM, van den Broek NM, Lindsey PJ, Schoonderwoerd KG, de Coo IF, Nicolay K, Prompers JJ, Smeets HJ, van Loon LJ. Physical activity is the key determinant of skeletal muscle mitochondrial function in type 2 diabetes. J Clin Endocrinol Metab 2012;97:32613269 .

37. Morino K, Petersen KF, Dufour S, Befroy D, Frattini J, Shatzkes N, Neschen S, White MF, Bilz S, Sono S, Pypaert M, Schulman GI. Reduced mitochondrial density and increased IRS-1 serine phosphorylation in muscle of insulin-resistant offspring of type 2 diabetic parents. J Clin Invest 2005; 115:3587-3593.

38. Ritov VB, Menshikova EV, He J, Ferrell RE, Goodpaster BH, Kelley DE. Deficiency of subsarcolemmal mitochondria in obesity and type 2 diabetes. Diabetes 2005;54:8-14.

39. Kizhakekuttu TJ, Wang J, Dharmashankar K, Ying R, Gutterman DD, Vita JA, Widlansky ME. Adverse alterations in mitochondrial function contribute to type 2 diabetes mellitus-related endothelial dysfunction in humans. Arterioscler Thromb Vasc Biol 2012;32:2531-2539.

40. Duncan JG, Fong JL, Medeiros DM, Finck BN, Kelly DP. Insulin-resistant heart exhibits a mitochondrial biogenic response driven by the peroxisome proliferator-activated receptor-alpha/PGC1alpha gene regulatory pathway. Circulation 2007;115:909-917.

41. Feige JN, Auwerx J. Transcriptional coregulators in the control of energy homeostasis. Trends Cell Biol 2007;17:292-301.

42. Canto C, Auwerx J. PGC-1alpha, SIRT1 and AMPK, an energy sensing network that controls energy expenditure. Curr Opin Lipidol 2009;20:98-105.

43. Rodgers JT, Lerin C, Haas W, Gygi SP, Spiegelman BM, Puigserver P. Nutrient control of glucose homeostasis through a complex of PGC-1alpha and SIRT1. Nature 2005;434:113-118.

44. Nisoli E, Carruba MO. Nitric oxide and mitochondrial biogenesis. J Cell Sci 2006;119:2855-2862.

45. Brown GC, Borutaite V. Nitric oxide, mitochondria, and cell death. IUBMB Life 2001;52:189-195.

46. Mo L, Wang Y, Geary L, Corey C, Alef MJ, Beer-Stolz D, Zuckerbraun BS, Shiva S. Nitrite activates AMP kinase to stimulate mitochondrial biogenesis independent of soluble guanylate cyclase. Free Radic Biol Med 2012;53:1440-1450.

47. Benton CR, Nickerson JG, Lally J, Han XX, Holloway GP, Glatz JF, Luiken JJ, Graham TE, Heikkila JJ, Bonen A. Modest PGC-1alpha overexpression in muscle in vivo is sufficient to increase insulin sensitivity and palmitate oxidation in subsarcolemmal, not intermyofibrillar, mitochondria. J Biol Chem 2008;283:4228-4240.

48. Lin J, Wu H, Tarr PT, Zhang CY, Wu Z, Boss O, Michael LF, Puigserver P, Isotani E, Olson EN, Lowell BB, Bassel-Duby R, Spiegelman BM. Transcriptional co-activator PGC-1 alpha drives the formation of slow-twitch muscle fibres. Nature 2002;418:797-801.

49. Mensink M, Hesselink MK, Russell AP, Schaart G, Sels JP, Schrauwen P. Improved skeletal muscle oxidative enzyme activity and restoration of PGC-1 alpha and PPAR beta/delta gene expression upon rosiglitazone treatment in obese patients with type 2 diabetes mellitus. Int $\mathbf{J}$ Obes (Lond) 2007;31:1302-1310.

50. Puigserver P, Wu Z, Park CW, Graves R, Wright M, Spiegelman BM. A cold-inducible coactivator of nuclear receptors linked to adaptive thermogenesis. Cell 1998;92:829-839.

51. Finck BN, Kelly DP. PGC-1 coactivators: Inducible regulators of energy metabolism in health and disease. J Clin Invest 2006;116:615-622.

52. Yoon JC, Puigserver P, Chen G, Donovan J, Wu Z, Rhee J, Adelmant G, Stafford J, Kahn CR, Granner DK, Newgard CB, Spiegelman BM. Control of hepatic gluconeogenesis through the transcriptional coactivator PGC-1. Nature 2001;413:131-138. 
53. Wu Z, Puigserver P, Andersson U, Zhang C, Adelmant G, Mootha V, Troy A, Cinti S, Lowell B, Scarpulla RC, Spiegelman BM. Mechanisms controlling mitochondrial biogenesis and respiration through the thermogenic coactivator PGC-1. Cell 1999;98:115-124.

54. Patti ME, Butte AJ, Crunkhorn S, Cusi K, Berria R, Kashyap S, Miyazaki Y, Kohane I, Costello M, Saccone R, Landaker EJ, Goldfine AB, Mun E, DeFronzo R, Finlayson J, Kahn CR, Mandarino LJ. Coordinated reduction of genes of oxidative metabolism in humans with insulin resistance and diabetes: Potential role of PGC1 and NRF1. Proc Natl Acad Sci USA 2003;100:8466-8471.

55. Ling C, Poulsen P, Carlsson E, Ridderstrale M, Almgren P, Wojtaszewski J, Beck-Nielsen H, Groop L, Vaag A. Multiple environmental and genetic factors influence skeletal muscle PGC-1alpha and PGC-1beta gene expression in twins. J Clin Invest 2004;114:1518-1526.

56. St-Pierre J, Lin J, Krauss S, Tarr PT, Yang R, Newgard CB, Spiegelman BM. Bioenergetic analysis of peroxisome proliferator-activated receptor gamma coactivators 1alpha and 1beta (PGC-1alpha and PGC-1beta) in muscle cells. J Biol Chem 2003;278:26597-26603.

57. Reznick RM, Shulman GI. The role of AMP-activated protein kinase in mitochondrial biogenesis. J Physiol 2006;574:33-39.

58. Winder WW, Holmes BF, Rubink DS, Jensen EB, Chen M, Holloszy JO. Activation of AMPactivated protein kinase increases mitochondrial enzymes in skeletal muscle. J Appl Physiol 2000;88:2219-2226.

59. Jager S, Handschin C, St-Pierre J, Spiegelman BM. AMP-activated protein kinase (AMPK) action in skeletal muscle via direct phosphorylation of PGC-1alpha.Proc Natl Acad Sci USA 2007;104:1201712022.

60. Friedrichsen M, Mortensen B, Pehmøller C, Birk JB, Wojtaszzewski JF. Exercise-induced AMPK activity in skeletal muscle: Role in glucose uptake and insulin sensitivity. Mol Cell Endocrinol 2013;366:204-214.

61. Mootha VK, Lindgren CM, Eriksson KF, Subramanian A, Sihag S, Lehar J, Puigserver P, Carlsson E, Ridderstrale M, Laurila E, Houstis N, Daly MJ, Patterson N, Mesirov JP, Golub TR, Tamayo P, Spiegelman B, Lander ES, Hirschhorn JN, Altshuler D, Groop LC. PGC-1alpha-responsive genes involved in oxidative phosphorylation are coordinately downregulated in human diabetes. Nat Genet 2003;34:267-273.

62. Victor VM, Rocha M, Herance R, Hernandez-Mijares A. Oxidative stress and mitochondrial dysfunction in type 2 diabetes. Curr Pharm Des 2011;17:3947-3958.

63. Victor VM, Rocha M, Bañuls C, Bellod L, Hernandez-Mijares A. Mitochondrial dysfunction and targeted drugs: A focus on diabetes. Curr Pharm Des 2011;17:1986-2001.

64. Houstek J, Pícková A, Vojtísková A, Mrácek T, Pecina P, Jesina P. Mitochondrial diseases and genetic defects of ATP synthase. Biochim Biophys Acta 2006;1757:1400-1405.

65. Wilson FH, Hariri A, Farhi A, Zhao H, Petersen KF, Toka HR, Nelson-Williams C, Raja KM, Kashgarian M, Shulman GI, Scheinman SJ, Lifton RP. A cluster of metabolic defects caused by mutation in a mitochondrial tRNA. Science 2004;306:1190-1194.

66. Cardaioli E, Malfatti E, Battisti C, Da Pozzo P, Rubegni A, Gallus GN, Malandrini A, Federico A. Sporadic myopathy, myoclonus, leukoencephalopathy, neurosensory deafness, hypertrophic cardiomyopathy and insulin resistance associated with the mitochondrial $8306 \mathrm{~T}>\mathrm{C}$ MTTK mutation. J Neurol Sci 2012;321:92-95.

67. He M, Rutledge SL, Kelly DR, Palmer CA, Murdoch G, Majumder N, Nicholls RD, Pei Z, Watkins PA, Vockley J. A new genetic disorder in mitochondrial fatty acid beta oxidation:ACAD9 deficiency. Am J Hum Genet 2007;81:87-103.

68. Maassen JA, T Hart LM, Van Essen E, Heine RJ, Nijpels G, Jahangir Tafrechi RS, Raap AK, Janssen GM, Lemkes HH. Mitochondrial diabetes: Molecular mechanisms and clinical presentation. Diabetes 2004;53:103-109.

69. Hirschey MD, Shimazu T, Jing E, Grueter CA, Collins AM, Aouizerat B, Stančáková A, Goetzman E, Lam MM, Schwer B, Stevens RD, Muehlbauer MJ, Kakar S, Bass NM, Kuusisto J, Laakso M, Alt FW, Newgard CB, Farese RV, Jr, Kahn CR, Verdin E. SIRT3 deficiency and mitochondrial protein 
22 - ROCHA ET AL.

hyperacetylation accelerate the development of the metabolic syndrome. Mol Cell 2011;44:177190.

70. Muller YL, Bogardus C, Pedersen O, Baier L. A Gly482Ser missense mutation in the peroxisome proliferator-activated receptor gamma coactivator-1 is associated with altered lipid oxidation and early insulin secretion in Pima Indians. Diabetes 2003;52:895-898.

71. Nishikawa T, Edelstein D, Du XL, Yamagishi S, Matsumura T, Kaneda Y, Yorek MA, Beebe D, Oates PJ, Hammes HP, Giardino I, Brownlee M. Normalizing mitochondrial superoxide production blocks three pathways of hyperglycaemic damage. Nature 2000;404:787-790.

72. Padmalayam I. Targeting mitochondrial oxidative stress through lipoic acid synthase: A novel strategy to manage diabetic cardiovascular disease. Cardiovasc Hematol Agents Med Chem 2012;10:223233.

73. Turrens JF, Boveris A. Generation of superoxide anion by the NADH dehydrogenase of bovine heart mitochondria. Biochem J 1980;191:421-427.

74. Murphy MP. How mitochondria produce reactive oxygen species. Biochem J 2009;417:1-13.

75. Verkaart S, Koopman WJ, Cheek J, van Emst-de Vries SE, van den Heuvel LW, Smeitink JA, Willems PH. Mitochondrial and cytosolic thiol redox state are not detectably altered in isolated human NADH: Ubiquinone oxidoreductase deficiency. Biochim Biophys Acta 2007;1772:10411051.

76. Victor VM, Rocha M, Bañuls C, Sanchez-Serrano M, Sola E, Gomez M, Hernandez-Mijares A. Mitochondrial complex I impairment in leukocytes from polycystic ovary syndrome patients with insulin resistance. J Clin Endocrinol Metab 2009;94:3505-3512.

77. Victor VM, Rocha M, Bañuls C, Alvarez A, de Pablo C, Sanchez-Serrano M, Gomez M, HernandezMijares A. Induction of oxidative stress and human leukocyte/endothelial cell interactions in polycystic ovary syndrome patients with insulin resistance. J Clin Endocrinol Metab 2011;96:31153122 .

78. Martín-Hernández E, García-Silva MT, Vara J, Campos Y, Cabello A, Muley R, Del Hoyo P, Martín MA, Arenas J. Renal pathology in children with mitochondrial diseases. Pediatr Nephrol 2005;20:1299-1305.

79. Persson MF, Franzen S, Catrina SB, Dallner G, Hansell P, Brismar K, Palm F. Coenzyme Q10 prevents GDP-sensitive mitochondrial uncoupling, glomerular hyperfiltration and proteinuria in kidneys from $\mathrm{db} / \mathrm{db}$ mice as a model of type 2 diabetes. Diabetologia 2012;55:1535-1543.

80. Hernandez-Mijares A, Rocha M, Rovira-Llopis S, Bañuls C, Bellod L, de Pablo C, Alvarez A, Roldan-Torres I, Sola-Izquierdo E, Victor VM. Human leukocyte/endothelial cell interactions and mitochondrial dysfunction in type 2 diabetic patients and their association with silent myocardial ischemia. Diabetes Care 2013.

81. Hausse AO, Aggoun Y, Bonnet D, Sidi D, Munnich A, Rötig A, Rustin P. Idebenone and reduced cardiac hypertrophy in Friedreich's ataxia. Heart 2002;87:346-349.

82. Weidemann F, Rummey C, Bijnens B, Störk S, Jasaityte R, Dhooge J, Baltabaeva A, Sutherland G, Schulz JB, Meier T. Mitochondrial protection with idebenone in cardiac or neurological outcome (MICONOS) study group. The heart in Friedreich ataxia: Definition of cardiomyopathy, disease severity, and correlation with neurological symptoms. Circulation 2012;125:1626-1634.

83. Green K, Brand MD, Murphy MP. Prevention of mitochondrial oxidative damage as a therapeutic strategy in diabetes. Diabetes 2004;53:S110-S118.

84. Strachan MW. Insulin and cognitive function. Lancet 2003;362:1253.

85. Morino K, Petersen KF, Schulman GI. Molecular mechanisms of insulin resistance in humans and their potential links with mitochondrial dysfunction. Diabetes 2006;55:9-15.

86. Han DH, Hansen PA, Host HH, Holloszy JO. Insulin resistance of muscle glucose transport in rats fed a high-fat diet: A reevaluation. Diabetes 1997;46:1761-1767.

87. Dresner A, Laurent D, Marcucci M, Griffin ME, Dufour S, Cline GW, Slezak LA, Andersen DK, Hundal RS, Rothman DL, Petersen KF, Schulman GI. Effects of free fatty acids on glucose transport and IRS-1-associated phosphatidylinositol 3-kinase activity. J Clin Invest 1999;103:253-259. 
88. Gupta A, Dey CS. PTEN, a widely known negative regulator of insulin/PI3K signaling, positively regulates neuronal insulin resistance. Mol Biol Cell 2012;23:3882-3898.

89. Steinberg HO, Chaker H, Leaming R, Johnson A, Brechtel G, Baron AD. Obesity/insulin resistance is associated with endothelial dysfunction. Implications for the syndrome of insulin resistance. $\mathbf{J}$ Clin Invest 1996;97:2601-2610.

90. Ouwens DM, Boer C, Fodor M, de Galan P, Heine RJ, Maassen JA, Diamant M. Cardiac dysfunction induced by high-fat diet is associated with altered myocardial insulin signalling in rats. Diabetologia 2005;48:1229-1237.

91. Sedaghat AR, Sherman A, Quon MJ. A mathematical model of metabolic insulin signaling pathways. Am J Physiol Endocrinol Metab 2002;283:1084-1101.

92. Pessin JE, Saltiel AR. Signaling pathways in insulin action: Molecular targets of insulin resistance. J Clin Invest 2000;106:165-169.

93. Zhande R, Mitchell JJ, Wu J, Sun XJ. Molecular mechanism of insulin-induced degradation of insulin receptor substrate 1. Mol Cell Biol 2002;22:1016-1026.

94. Vinciguerra M, Foti M. PTEN and SHIP2 phosphoinositide phosphatases as negative regulators of insulin signalling. Arch Physiol Biochem 2006;112:89-104.

95. Zick Y. Ser/Thr phosphorylation of IRS proteins: A molecular basis for insulin resistance. Sci STKE 2005;2005:4.

96. Stratford S, Hoehn KL, Liu F, Summers SA. Regulation of insulin action by ceramide: Dual mechanisms linking ceramide accumulation to the inhibition of Akt/protein kinase B. J Biol Chem 2004;279:36608-36615.

97. Cusi K, Maezono K, Osman A, Pendergrass M, Patti ME, Pratipanawatr T, DeFronzo RA, Kahn CR, Mandarino LJ. Insulin resistance differentially affects the PI-3-kinase- and MAP kinasemediated signaling in human muscle. J Clin Invest 2000;105:311-320.

98. Pratipanawatr W, Pratipanawatr T, Cusi K, Berria R, Adams JM, Jenkinson CP, Maezono K, DeFronzo RA, Mandarino LJ. Skeletal muscle insulin resistance in normoglycemic subjects with a strong family history of type 2 diabetes is associated with decreased insulin-stimulated insulin receptor substrate-1 tyrosine phosphorylation. Diabetes 2001;50:2572-2578.

99. Shi H, Kokoeva MV, Inouye K, Tzameli I, Yin H, Flier JS. TLR4 links innate immunity and fatty acid-induced insulin resistance. J Clin Invest 2006;116:3015-3025.

100. Kim F, Pham M, Luttrell I, Bannerman DD, Tupper J, Thaler J, Hawn TR, Raines EW, Schwartz MW. Toll-like receptor-4 mediates vascular inflammation and insulin resistance in diet-induced obesity. Circ Res 2007;100:1589-1596.

101. Kim JK, Kim YJ, Fillmore JJ, Chen Y, Moore I, Lee J, Yuan M, Li ZW, Karin M, Perret P, Shoelson SE, Shulman GI. Prevention of fat-induced insulin resistance by salicylate. J Clin Invest 2001;108:437-446.

102. Cai D, Yuan M, Frantz DF, Melendez PA, Hansen L, Lee J, Shoelson SE. Local and systemic insulin resistance resulting from hepatic activation of IKK-beta and NF-kappaB. Nat Med 2005;11:183190.

103. Ozcan U, Yilmaz E, Ozcan L, Furuhashi M, Vaillancourt E, Smith RO, Görgün CZ, Hotamisligil GS. Chemical chaperones reduce ER stress and restore glucose homeostasis in a mouse model of type 2 diabetes. Science 2006;313:1137-1140.

104. Flamment M, Hajduch E, Ferré P, Foufelle F. New insights into ER stress-induced insulin resistance. Trends Endocrinol Metab 2012;23:381-390.

105. Nishikawa T, Araki E. Impact of mitochondrial ROS production in the pathogenesis of diabetes mellitus and its complications. Antioxid Redox Signal 2007;9:343-353.

106. Itani SI, Ruderman NB, Schmieder F, Boden G. Lipid-induced insulin resistance in human muscle is associated with changes in diacylglycerol, protein kinase C, and IkappaB-alpha. Diabetes 2002;51:2005-2011.

107. Yu C, Chen Y, Cline GW, Zhang D, Zong H, Wang Y, Bergeron R, Kim JK, Cushman SW, Cooney GJ, Atcheson B, White MF, Kraegen EW, Shulman GI. Mechanism by which fatty acids inhibit 


\section{4 - ROCHA ET AL.}

insulin activation of insulin receptor substrate-1 (IRS-1)-associated phosphatidylinositol 3-kinase activity in muscle. J Biol Chem 2002;277:50230-50236.

108. Kim JK, Fillmore JJ, Sunshine MJ, Albrecht B, Higashimori T, Kim DW, Liu ZX, Soos TJ, Cline GW, O'Brien WR, Littman DR, Shulman GI. PKC-theta knockout mice are protected from fat-induced insulin resistance. J Clin Invest 2004;114:823-827.

109. Petersen KF, Dufour S, Befroy D, Garcia R, Shulman GI. Impaired mitochondrial activity in insulin-resistant offspring of patients with type 2 diabetes. N Engl J Med 2004;350:664671.

110. Kim JY, Hickner RC, Cortright RL, Dohm GL, Houmard JA. Lipid oxidation is reduced in obese human skeletal muscle. Am J Physiol Endocrinol Metab 2000;279:1039-1044.

111. Boden G. Fatty acid-induced inflammation and insulin resistance in skeletal muscle and liver. Curr Diab Rep 2006;6:177-181.

112. Oseid S, Beck-Nielsen H, Pedersen O, Sovik O. Decreased binding of insulin to its receptor in patients with congenital generalized lipodystrophy. N Engl J Med 1977;296:245-248.

113. Banerjee RR, Rangwala SM, Shapiro JS, Rich AS, Rhoades B, Qi Y, Wang J, Rajala MW, Pocai A, Scherer PE, Steppan CM, Ahima RS, Obici S, Rossetti L, Lazar MA. Regulation of fasted blood glucose by resistin. Science 2004;303:1195-1198.

114. Yamauchi T, Kamon J, Waki H, Terauchi Y, Kubota N, Hara K, Mori Y, Ide T, Murakami K, Tsuboyama-Kasaoka N, Ezaki O, Akanuma Y, Gavrilova O, Vinson C, Reitman ML, Kagechika H, Shudo K, Yoda M, Nakano Y, Tobe K, Nagai R, Kimura S, Tomita M, Froguel P, Kadowaki T. The fat-derived hormone adiponectin reverses insulin resistance associated with both lipoatrophy and obesity. Nat Med 2001;7:941-946.

115. Yamauchi T, Kamon J, Waki H, Terauchi Y, Kubota N, Hara K, Mori Y, Ide T, Murakami K, Tsuboyama-Kasaoka N, Ezaki O, Akanuma Y, Gavrilova O, Vinson C, Reitman ML, Kagechika H, Shudo K, Yoda M, Nakano Y, Tobe K, Nagai R, Kimura S, Tomita M, Froguel P, Kadowaki T. The fat-derived hormone adiponectin reverses insulin resistance associated with both lipoatrophy and obesity. Nat Med 2001;7:941-946.

116. Bogacka I, Xie H, Bray GA, Smith SR. Pioglitazone induces mitochondrial biogenesis in human subcutaneous adipose tissue in vivo. Diabetes 2005;54:1392-1399.

117. Kostis JB, Sanders M. The association of heart failure with insulin resistance and the development of type 2 diabetes. Am J Hypertens 2005;18:731-737.

118. Ferrannini E, Cushman WC. Diabetes and hypertension: The bad companions. Lancet 2012;380:601-610.

119. Boudina S, Sena S, O'Neill BT, Tathireddy P, Young ME, Abel ED. Reduced mitochondrial oxidative capacity and increased mitochondrial uncoupling impair myocardial energetics in obesity. Circulation 2005;112:2686-2695.

120. Christoffersen C, Bollano E, Lindegaard ML, Bartels ED, Goetze JP, Andersen CB, Nielsen LB. Cardiac lipid accumulation associated with diastolic dysfunction in obese mice. Endocrinology 2003;144:3483-3490.

121. Goldberg IJ, Trent CM, Schulze PC. Lipid metabolism and toxicity in the heart. Cell Metab 2012;15:805-812.

122. McGavock JM, Lingvay I, Zib I, Tillery T, Salas N, Unger R, Levine BD, Raskin P, Victor RG, Szczepaniak LS. Cardiac steatosis in diabetes mellitus: A 1H-magnetic resonance spectroscopy study. Circulation 2007;116:1170-1175.

123. Whaley-Connell A, Govindarajan G, Habibi J, Hayden MR, Cooper SA, Wei Y, Ma L, Qazi M, Link D, Karuparthi PR, Stump C, Ferrario C, Sowers JR. Angiotensin II-mediated oxidative stress promotes myocardial tissue remodeling in the transgenic (mRen2) 27 Ren2 rat. Am J Physiol Endocrinol Metab 2007;293:E355-E363.

124. Katakam PV, Jordan JE, Snipes JA, Tulbert CD, Miller AW, Busija DW. Myocardial preconditioning against ischemia-reperfusion injury is abolished in Zucker obese rats with insulin resistance. Am J Physiol Regul Integr Comp Physiol 2007;292:920-926. 
125. Nishio Y, Kanazawa A, Nagai Y, Inagaki H, Kashiwagi A. Regulation and role of the mitochondrial transcription factor in the diabetic rat heart. Ann N Y Acad Sci 2004;1011:78-85.

126. Suematsu N, Tsutsui H, Wen J, Kang D, Ikeuchi M, Ide T, Hayashidani S, Shiomi T, Kubota T, Hamasaki N, Takeshita A. Oxidative stress mediates tumor necrosis factor-alpha-induced mitochondrial DNA damage and dysfunction in cardiac myocytes. Circulation 2003;107:1418-1423.

127. Finck BN, Kelly DP. Peroxisome proliferator-activated receptor gamma coactivator-1 (PGC-1) regulatory cascade in cardiac physiology and disease. Circulation 2007;115:2540-2548.

128. Kim JA, Montagnani M, Koh KK, Quon MJ. Reciprocal relationships between insulin resistance and endothelial dysfunction: Molecular and pathophysiological mechanisms. Circulation 2006;113:1888-1904.

129. Culic O, Gruwel ML, Schrader J. Energy turnover of vascular endothelial cells. Am J Physiol 1997;273:205-213.

130. Davidson SM, Duchen MR. Endothelial mitochondria: Contributing to vascular function and disease. Circ Res 2007;100:1128-1141.

131. Nishikawa T, Edelstein D, Du XL, Yamagishi S, Matsumura T, Kaneda Y, Yorek MA, Beebe D, Oates PJ, Hammes HP, Giardino I, Brownlee M. Normalizing mitochondrial superoxide production blocks three pathways of hyperglycaemic damage. Nature 2000;404:787-790.

132. Zheng Z, Chen H, Ke G, Fan Y, Zou H, Sun X, Gu Q, Xu X, Ho PC. Protective effect of perindopril on diabetic retinopathy is associated with decreased vascular endothelial growth factor-to-pigment epithelium-derived factor ratio: Involvement of a mitochondria-reactive oxygen species pathway. Diabetes 2009;58:954-964.

133. Montagnani M, Chen H, Barr VA, Quon MJ. Insulin-stimulated activation of eNOS is independent of $\mathrm{Ca} 2$ + but requires phosphorylation by Akt at Ser(1179). J Biol Chem 2001;276:30392-30398.

134. Duplain H, Burcelin R, Sartori C, Cook S, Egli M, Lepori M, Vollenweider P, Pedrazzini T, Nicod $\mathrm{P}$, Thorens B, Scherrer U. Insulin resistance, hyperlipidemia, and hypertension in mice lacking endothelial nitric oxide synthase. Circulation 2001;104:342-345.

135. Maechler $\mathrm{P}$, Wollheim CB. Mitochondrial function in normal and diabetic beta-cells. Nature 2001;414:807-812.

136. Han J, Bae JH, Kim SY, Lee HY, Jang BC, Lee IK, Cho CH, Lim JG, Suh SI, Kwon TK, Park JW, Ryu SY, Ho WK, Earm YE, Song DK. Taurine increases glucose sensitivity of UCP2overexpressing beta-cells by ameliorating mitochondrial metabolism. Am J Physiol Endocrinol Metab 2004;287:E1008-1018.

137. Soejima A, Inoue K, Takai D, Kaneko M, Ishihara H, Oka Y, Hayashi JI. Mitochondrial DNA is required for regulation of glucose-stimulated insulin secretion in a mouse pancreatic beta cell line, MIN6. J Biol Chem 1996;271:26194-26199.

138.

139. Serviddio G, Bellanti F, Sastre J, Vendemiale G, Altomare E. Targeting mitochondria: A new promising approach for the treatment of liver diseases. Curr Med Chem. 2010;17:2325-2337.

140. Murphy MP, Smith RA. Targeting antioxidants to mitochondria by conjugation to lipophilic cations. Annu Rev Pharmacol Toxicol 2007;47:629-656.

141. Szeto HH. Cell-permeable, mitochondrial-targeted, peptide antioxidants. AAPS J 2006;8:277-283.

142. Ross MF, Prime TA, Abakumova I, James AM, Porteous CM, Smith RA, Murphy MP. Rapid and extensive uptake and activation of hydrophobic triphenylphosphonium cations within cells. Biochem J 2008;411:633-645.

143. Porteous CM, Logan A, Evans C, Ledgerwood EC, Menon DK, Aigbirhio F, Smith RA, Murphy MP. Rapid uptake of lipophilic triphenylphosphonium cations by mitochondria in vivo following intravenous injection: Implications for mitochondria-specific therapies and probes. Biochim Biophys Acta 2010;1800:1009-1017.

144. Rodriguez-Cuenca S, Cochemé HM, Logan A, Abakumova I, Prime TA, Rose C, Vidal-Puig A, Smith AC, Rubinsztein DC, Fearnley IM, Jones BA, Pope S, Heales SJ, Lam BY, Neogi SG, McFarlane I, James AM, Smith RA, Murphy MP. Consequences of long-term oral administration of 
26 - ROCHA ET AL.

the mitochondria-targeted antioxidant MitoQ to wild-type mice. Free Radic Biol Med 2010;48:161172.

145. Teicher BA, Holden SA, Cathcart KN. Efficacy of $\mathrm{Pt}(\mathrm{Rh}-123) 2$ as a radiosensitizer with fractionated X rays. Int J Radiat Oncol Biol Phys 1987;13:1217-1224.

146. Robertson L, Hartley RC. Synthesis of N-arylpyridinium salts bearing a nitrone spin trap as potential mitochondria-targeted antioxidants. Tetrahedron 2009;65:5284-5292.

147. James AM, Cochemé HM, Smith RA, Murphy MP. Interactions of mitochondria-targeted and untargeted ubiquinones with the mitochondrial respiratory chain and reactive oxygen species. Implications for the use of exogenous ubiquinones as therapies and experimental tools. J Biol Chem. 2005;280:21295-21312.

148. James AM, Sharpley MS, Manas AR, Frerman FE, Hirst J, Smith RA, Murphy MP. Interaction of the mitochondria-targeted antioxidant MitoQ with phospholipid bilayers and ubiquinone oxidoreductases. J Biol Chem 2007;282:14708-14718.

149. Smith RA, Porteous CM, Coulter CV, Murphy MP. Selective targeting of an antioxidant to mitochondria. Eur J Biochem 1999;263:709-716.

150. Biasutto L, Mattarei A, Marotta E, Bradaschia A, Sassi N, Garbisa S, Zoratti M, Paradisi C. Development of mitochondria-targeted derivatives of resveratrol. Bioorg Med Chem Lett. 2008;18:5594 5597.

151. Filipovska A, Kelso GF, Brown SE, Beer SM, Smith RA, Murphy MP. Synthesis and characterization of a triphenylphosphonium-conjugated peroxidase mimetic. Insights into the interaction of ebselen with mitochondria. J Biol Chem 2005;280:24113-24126.

152. Brown SE, Ross MF, Sanjuan-Pla A, Manas AR, Smith RA, Murphy MP. Targeting lipoic acid to mitochondria: Synthesis and characterization of a triphenylphosphonium-conjugated alpha-lipoyl derivative. Free Radic Biol Med 2007;42:1766-1780.

153. Trnka J, Blaikie FH, Smith RA, Murphy MP. A mitochondria-targeted nitroxide is reduced to its hydroxylamine by ubiquinol in mitochondria. Free Radic Biol Med 2008;44:14061419 .

154. Skulachev VP, Anisimov VN, Antonenko YN, Bakeeva LE, Chernyak BV, Erichev VP, Filenko OF, Kalinina NI, Kapelko VI, Kolosova NG, Kopnin BP, Korshunova GA, Lichinitser MR, Obukhova LA, Pasyukova EG, Pisarenko OI, Roginsky VA, Ruuge EK, Senin II, Severina II, Skulachev MV, Spivak IM, Tashlitsky VN, Tkachuk VA, Vyssokikh MY, Yaguzhinsky LS, Zorov DB. An attempt to prevent senescence: A mitochondrial approach. Biochim Biophys Acta 2009;1787:437461.

155. Murphy MP, Echtay KS, Blaikie FH, Asin-Cayuela J, Cocheme HM, Green K, Buckingham JA, Taylor ER, Hurrell F, Hughes G, Miwa S, Cooper CE, Svistunenko DA, Smith RA, Brand MD. Superoxide activates uncoupling proteins by generating carbon-centered radicals and initiating lipid peroxidation: Studies using a mitochondria-targeted spin trap derived from alpha-phenyl-N-tertbutylnitrone. J Biol Chem 2003;278:48534 48545.

156. Asin-Cayuela J, Manas AR, James AM, Smith RA, Murphy MP. Fine-tuning the hydrophobicity of a mitochondria-targeted antioxidant. FEBS Lett 2004;571:9-16.

157. Kelso GF, Porteous CM, Coulter CV, Hughes G, Porteous WK, Ledgerwood EC, Smith RA, Murphy MP. Selective targeting of a redox-active ubiquinone to mitochondria within cells: Antioxidant and antiapoptotic properties. J Biol Chem 2001;276:4588-4596.

158. Maroz A, Anderson RF, Smith RA, Murphy MP. Reactivity of ubiquinone and ubiquinol with superoxide and the hydroperoxyl radical: Implications for in vivo antioxidant activity. Free Radic Biol Med 2009;46:105-109.

159. Smith RA, Murphy MP. Mitochondria-targeted antioxidants as therapies. Discov Med 2011;11:106114.

160. Pletjushkina OY, Lyamzaev KG, Popova EN, Nepryakhina OK, Ivanova OY, Domnina LV, Chernyak BV, Skulachev VP. Effect of oxidative stress on dynamics of mitochondrial reticulum. Biochim Biophys Acta 2006;1757:518-524. 
161. Lim S, Rashid MA, Jang M, Kim Y, Won H, Lee J, Woo JT, Kim YS, Murphy MP, Ali L, Ha J, Kim SS. Mitochondria-targeted antioxidants protect pancreatic $\beta$-cells against oxidative stress and improve insulin secretion in glucotoxicity and glucolipotoxicity. Cell Physiol Biochem 2011;28:873886.

162. Li J, Chen X, Xiao W, Ma W, Li T, Huang J, Liu X, Liang X, Tang S, Luo Y. Mitochondria-targeted antioxidant peptide SS31 attenuates high glucose-induced injury on human retinal endothelial cells. Biochem Biophys Res Commun 2011;404:349-356.

163. Esplugues JV, Rocha M, Nuñez C, Bosca I, Ibiza S, Herance JR, Ortega A, Serrador JM, D'Ocon P, Victor VM. Complex I dysfunction and tolerance to nitroglycerin: An approach based on mitochondrial-targeted antioxidants. Circ Res 2006;99:1067-1075.

164. Garcia-Bou R, Rocha M, Apostolova N, Herance R, Hernandez-Mijares A, Victor VM. Evidence for a relationship between mitochondrial complex I activity and mitochondrial aldehyde dehydrogenase during nitroglycerin tolerance: Effects of mitochondrial antioxidants. Biochim Biophys Acta 2012;1817:828-837.

165. Chacko BK, Reily C, Srivastava A, Johnson MS, Ye Y, Ulasova E, Agarwal A, Zinn KR, Murphy MP, Kalyanaraman B, Darley-Usmar V. Prevention of diabetic nephropathy in Ins2(+/)(AkitaJ) mice by the mitochondria-targeted therapy MitoQ. Biochem J 2010;432;9-19.

166. Mercer JR, Yu E, Figg N, Cheng KK, Prime TA, Griffin JL, Masoodi M, Vidal-Puig A, Murphy MP, Bennett MR. The mitochondria-targeted antioxidant MitoQ decreases features of the metabolic syndrome in ATM+/-/ApoE-/- mice. Free Radic Biol Med 2012;52:841-849.

167. Pung YF, Rocic P, Murphy MP, Smith RA, Hafemeister J, Ohanyan V, Guarini G, Yin L, Chilian WM. Resolution of mitochondrial oxidative stress rescues coronary collateral growth in Zucker obese fatty rats. Arterioscler Thromb Vasc Biol 2012;32:325-334.

168. Stone WL, Smith M. Therapeutic uses of antioxidant liposomes. Mol Biotechnol 2004;27:217230.

169. Alipour M, Omri A, Smith MG, Suntres ZE. Prophylactic effect of liposomal N-acetylcysteine against LPS-induced liver injuries. JEndotoxin Res 2007;13:297-304.

170. Di Sario A, Bendia E, Taffetani S, Omenetti A, Candelaresi C, Marzioni M, De Minicis S, Benedetti A. Hepatoprotective and antifibrotic effect of a new silybin-phosphatidylcholine-Vitamin E complex in rats. Dig Liver Dis 2005;37:869-876.

171. Loguercio C, Federico A, Trappoliere M, Tuccillo C, de Sio I, Di Leva A, Niosi M, D'Auria MV, Capasso R, Del Vecchio Blanco C; Real Sud Group. The effect of a silybin-vitamin ephospholipid complex on nonalcoholic fatty liver disease: A pilot study. Dig Dis Sci 2007;52:23872395.

172. Kogure K, Akita H, Yamada Y, Harashima H. Multifunctional envelope-type nano device (MEND) as a non-viral gene delivery system. Adv Drug Deliv Rev 2008;60:559-571.

173. Yamada Y, Harashima H. Mitochondrial drug delivery systems for macromolecule and their therapeutic application to mitochondrial diseases. Adv Drug Deliv Rev 2008;60:1439 1462.

174. Yamada Y, Harashima H. Enhancement in selective mitochondrial association by direct modification of a mitochondrial targeting signal peptide on a liposomal based nanocarrier. Mitochondrion 2012.

175. Zhao K, Zhao GM, Wu D, Soong Y, Birk AV, Schiller PW, Szeto HH. Cell-permeable peptide antioxidants targeted to inner mitochondrial membrane inhibit mitochondrial swelling, oxidative cell death, and reperfusion injury. J Biol Chem 2004;279:34682-34690.

176. Yousif LF, Stewart KM, Kelley SO. Targeting mitochondria with organelle-specific compounds: Strategies and applications. Chembiochem 2009;10:1939-1950.

177. Zhao K, Luo G, Zhao GM, Schiller PW, Szeto HH. Transcellular transport of a highly polar 3+ net charge opioid tetrapeptide. J Pharmacol Exp Ther 2003;304:425-432.

178. Szeto HH, Schiller PW. Novel therapies targeting inner mitochondrial membrane - from discovery to clinical development. Pharm Res 2011;28:2669-2679. 
179. Szeto HH. Cell-permeable, mitochondrial-targeted, peptide antioxidants. AAPS J 2006;8:E277E283.

180. Manczak M, Mao P, Calkins MJ, Cornea A, Reddy AP, Murphy MP, Szeto HH, Park B, Reddy $\mathrm{PH}$. Mitochondria-targeted antioxidants protect against amyloid-beta toxicity in Alzheimer's disease neurons. J Alzheimers Dis 2010;20(Suppl 2):S609-S631.

181. Whiteman M, Spencer JP, Szeto HH, Armstrong JS. Do mitochondriotropic antioxidants prevent chlorinative stress-induced mitochondrial and cellular injury? Antioxid Redox Signal 2008;10:641650 .

182. Yousif LF, Stewart KM, Horton KL, Kelley SO. Mitochondria-penetrating peptides: Sequence effects and model cargo transport. Chembiochem 2009;10:2081-2088.

183. Fink MP, Macias CA, Xiao J, Tyurina YY, Delude RL, Greenberger JS, Kagan VE, Wipf P. Hemigramicidin-TEMPO conjugates: Novel mitochondria-targeted antioxidants. Crit Care Med 2007;35:461-467.

184. Macias CA, Chiao JW, Xiao J, Arora DS, Tyurina YY, Delude RL, Wipf P, Kagan VE, Fink MP. Treatment with a novel hemigramicidin-TEMPO conjugate prolongs survival in a rat model of lethal hemorrhagic shock. Ann Surg 2007;245:305-314.

185. Marrache S, Dhar S. Engineering of blended nanoparticle platform for delivery of mitochondriaacting therapeutics. Proc Natl Acad Sci USA 2012;109:16288-16293.

Milagros Rocha obtained his undergraduate degree at Madrid's Complutense University in 1995 and obtained her Ph.D. in 2003, focusing on the control of sexual steroids on segregated products by adipose tissues and the hypothalamic neuropeptides implicated in food intake. As postdoctoral researcher, Dr. M Rocha was at University of Valencia and University Hospital Doctor Peset from 2004 to 2010. She is now a Miguel Servet researcher of ISCIII at UniversityHospital Doctor Peset. She has spent time working in different international and national research centers, including the University of Liverpool (Dr. G Williams), and the Barcelona Biomedical Research Group (PRBB) (Dr. R. Herance). Currently, Dr. Rocha's work focuses on:

1. Analysis of lipid profile, inflammatory parameters, and evaluation of endothelial and mitochondrial function in insulin-resistance states, such as type 2 diabetes mellitus, obesity, metabolic syndrome, and polycystic ovary syndrome.

2. Influence of functional foods in cardiovascular risk, inflammation, and oxidation.

3. Hypolipemic pharmacological agents and endothelial dysfunction.

Dr. Rocha has been the main investigator of several regional funded competitive research projects and has published more than 40 articles in different international journals, including Circulation Research, Hepatology, JCEM, Fertility and Sterility, and Journal of Nutritional Biochemistry.

Nadezda Apostolova obtained her degree in Biology (Biochemistry and Physiology) in 2001 at the Faculty of Mathematics and Natural Sciences, University "St. Cyril and Methodius," Macedonia. She then obtained M.Sc. degree in 2005 and her Ph.D. at the University of Valencia (Valencia, Spain) as Ph.D. fellow of the Spanish Ministry of Education. From 2008 to 2011, Nadezda worked as postdoctoral fellow at CIBERehd in Valencia and since then is employed as a postdoctoral researcher at the Department of Pharmacology, Faculty of Medicine, University of Valencia, presently as postdoctoral fellow of the Spanish Ministry of Science. She has participated in a dozen publicly funded research projects from the Spanish national and local funding agencies 
and is an author of 19 original peer-reviewed papers, eight review articles and one editorial as guest editor. She has had more than 40 communications in national and international meetings and has supervised several doctoral and master theses. Nadezda has won several awards including the award of the best graduated student at the Faculty of Mathematics and Natural Sciences at "St. Cyril and Methodius" University for the year 2001 or the EPHAR Young Investigator Award in 2011. Her research over the last years has been focused on the participation of mitochondria in cellular pathophysiology regarding parameters, such as oxidative stress, survival mechanisms, and induction of cell-death programs. Recently, her investigation has had a special emphasis on deciphering the bases of several pharmacological mitotoxicites in cellular models.

Raul Herance was born in 1976 in Sabadell, Spain. In 1995, he obtained his degree in chemistry from the Autonomous University of Barcelona. In 2000, he completed his Ph.D. in organic chemistry at the Department of Chemistry, Autonomous University of Barcelona. Then, from 2005 till present, he started to join radiopharmaceutical products of the Private Foundation High Technology Institute/CRC Molecular Imaging Center as a head of the Research and Development Chemistry Department. In addition, he is member of the research and development scientific committee of this institution since 2006. His areas of interest are radiochemistry, medicinal chemistry, synthetic organic chemistry, material chemistry, nanomedicine, biotechnology, photochemistry, and oxidative stress.

Susana Rovira-Llopis (1985, Valencia, Spain) obtained her degree in Biology in 2008 at the Faculty of Biological Sciences, University of Valencia, Spain. She then obtained a master's degree in Molecular and Cellular Biology and Genetics in 2009 at the Faculty of Biological Sciences, University of Valencia, Spain. From 2008 to 2010 Susana worked as a senior laboratory technician in the Institute of Biomedicine of Valencia. Since 2011, she has worked as predoctoral fellow of the FIS (Fondo de Investigación Sanitaria, Instituto de Salud Carlos III, Spain) in the University Hospital Doctor Peset in Valencia, Spain. She is focused on the pathophysiological and therapeutic implications of mitochondrial dysfunction in type 2 diabetes.

Antonio Hernandez-Mijares specializes in Internal Medicine in 1976 and in Endocrinology and Nutrition in1980. Professor of Medicine at the University of Valencia since 1992. He currently works at University Hospital Doctor Peset (Valencia) where he is chief of Endocrinology and Nutrition since 1995, director of the Diabetes Reference Unit and Lipid Unit since 1996, and chairman of the Research Committee. He has published more than 200 peer-reviewed papers and written more than 60 book chapters. He has conducted several research projects sponsored by the Ministry of Health of Spain. He is also an advisor to the Valencian regional government on endocrinology and diabetes.

Victor M. Victor obtained his degree at Madrid's Complutense University in 1995. He subsequently trained as a postgraduate student in the laboratory of Dr. Monica de la Fuente at the Department of Physiology of the same university, where he obtained his Ph.D. in 2001 in the role of antioxidants in immune function in murine models of endotoxic shock. After a 6-year period at CNIC (National Centre of Cardiovascular Disease Research) from 2002 to 2008, he is now a researcher at University Hospital Doctor Peset and an associate professor at the Faculty of Medicine, University of Valencia. Over the years, Dr. Victor has also spent time in different laboratories in Cambridge, London, Dublin, and New York analyzing different aspects of mitochondrial bioenergetics and related diseases. Nowadays Dr. Victor's work focuses on mitochondrial and endothelial dysfunction and related diseases, such as type 2 diabetes and metabolic syndrome. Additionally, he is involved in the following lines of research: ( $i$ ) the role of mitochondria-targeted 
30 - ROCHA ET AL.

antioxidants in different models of oxidative stress. (ii) The potential role of nanoparticles in antioxidant function. (iii) The effect of different drugs in lipid profile. Dr. Victor has been the principal investigator of several nationally funded research projects and has published more than 70 articles in different international journals including Diabetes Care, Circulation Research, Immunity, PNAS, Hepatology, and JCEM. He is an international reviewer and member of the editorial board of several journals.

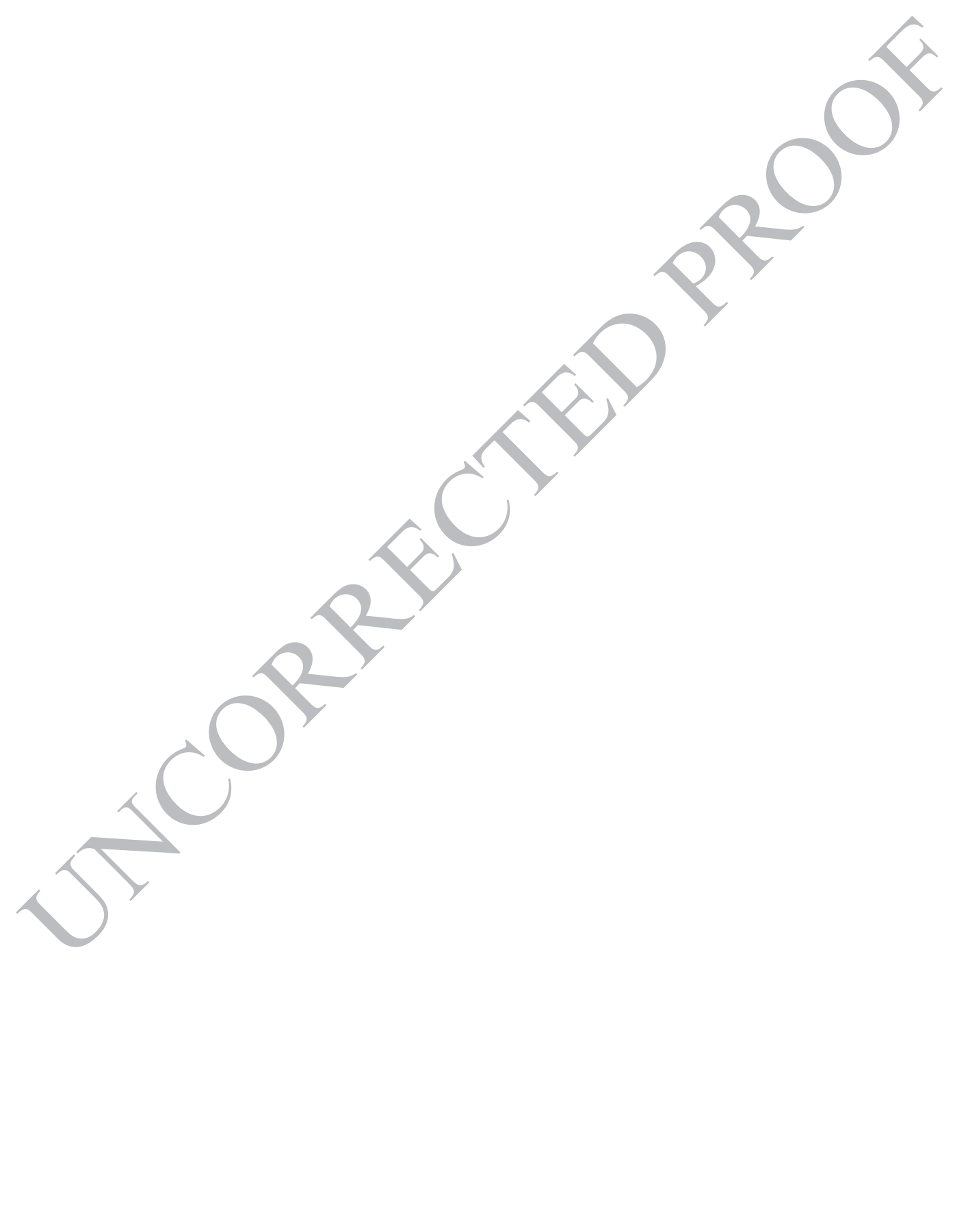


Autbor Query Form

\begin{tabular}{ll}
\hline Journal & MED \\
Article & med21285
\end{tabular}

Dear Author

During the copy-editing of your paper, the following queries arose. Please respond to these by marking up your proofs with the necessary changes/additions. Please write your answers clearly on the query sheet if there is insufficient space on the page proofs. If returning the proof by fax do not write too close to the paper's edge. Please remember that illegible mark-ups may delay publication.

\begin{tabular}{|c|c|c|}
\hline Query No. & Description & Author Response \\
\hline Q1 & $\begin{array}{l}\text { Author: Please check all the affiliations as typeset for } \\
\text { correctness. }\end{array}$ & \\
\hline Q2 & $\begin{array}{l}\text { Wiley: Please check the information regarding author } \\
\text { contribution as typeset for correctness. }\end{array}$ & \\
\hline Q3 & $\begin{array}{l}\text { Author: Please check the grant information as typeset } \\
\text { for correctness. }\end{array}$ & \\
\hline Q4 & $\begin{array}{l}\text { Author: Two correspondence authors were provided for } \\
\text { this article. The author "Milagros Rocha" has been set as } \\
\text { additional corresponding author. Please check for cor- } \\
\text { rectness. }\end{array}$ & \\
\hline Q5 & $\begin{array}{l}\text { Author: Please provide department's name in the cor- } \\
\text { respondence address. Also, please check the correspon- } \\
\text { dence details as typeset for correctness. }\end{array}$ & \\
\hline Q6 & $\begin{array}{l}\text { Author: Please check all the heading levels as typeset for } \\
\text { correctness. }\end{array}$ & \\
\hline Q7 & $\begin{array}{l}\text { Author: Please provide full form of NADH and } \mathrm{FADH}_{2} \\
\text { in sentence "ETC is located in the ...". }\end{array}$ & \\
\hline Q8 & $\begin{array}{l}\text { Author: A running head short title was not supplied; } \\
\text { please check if this one is suitable and, if not, please } \\
\text { supply a short title that can be used instead. }\end{array}$ & \\
\hline Q9 & $\begin{array}{l}\text { Author: Please check all the figure captions as typeset } \\
\text { for correctness. }\end{array}$ & \\
\hline Q10 & $\begin{array}{l}\text { Author: Please check the insertion of word "peroxisome" } \\
\text { in sentence "Other studies have reported ..." for cor- } \\
\text { rectness. }\end{array}$ & \\
\hline Q11 & $\begin{array}{l}\text { Author: Reference [138] has not been included in the } \\
\text { Reference List, please supply full publication details. }\end{array}$ & \\
\hline
\end{tabular}




\begin{tabular}{|c|c|c|}
\hline$\overline{\text { Q12 }}$ & $\begin{array}{l}\text { Author: Please check Table I and its footnote as typeset } \\
\text { for correctness. }\end{array}$ & \\
\hline Q13 & $\begin{array}{l}\text { Author: Reference list provided after Table I has been } \\
\text { considered as footnote of Table I and so is linked with } \\
\text { the table body with "a". References in the table and list } \\
\text { have been renumbered to maintain sequential order of } \\
\text { appearance. Please check for correctness. Wiley: Please } \\
\text { check issue numbers appearing in the references list set } \\
\text { in footnote of Table I. }\end{array}$ & \\
\hline Q14 & $\begin{array}{l}\text { Author: Please provide volume number and page range } \\
\text { in reference (Mackenzie et al., } 2012 \text { [Ref. 9]). }\end{array}$ & \\
\hline Q15 & $\begin{array}{l}\text { Author: Please provide full form of "NF- } \kappa \mathrm{B} \text { " in sentence } \\
\text { "Results in } \beta \text {-cells under oxidative stress ...". }\end{array}$ & \\
\hline Q16 & $\begin{array}{l}\text { Author: Please checkl the term "inclose" used in the } \\
\text { sentence "Liposomal carriers ..." for correctness. }\end{array}$ & \\
\hline Q17 & $\begin{array}{l}\text { Author: Please provide full form of NAFLD in sentence } \\
\text { "Siliphos has been shown ...". }\end{array}$ & \\
\hline Q18 & $\begin{array}{l}\text { Author: Please check citation of reference [183] in sen- } \\
\text { tence "XJB-5-131 is an electron and ROS ..." for cor- } \\
\text { rectness. }\end{array}$ & \\
\hline Q19 & $\begin{array}{l}\text { Author: Please provide volume number and page range } \\
\text { in reference [12]. }\end{array}$ & \\
\hline $\mathbf{Q 2 0}$ & $\begin{array}{l}\text { Author: Please provide volume number and page range } \\
\text { in reference [80]. }\end{array}$ & \\
\hline Q21 & $\begin{array}{l}\text { Author: If this is not a one-page article please supply the } \\
\text { first and last pages for this article in reference [84]. }\end{array}$ & \\
\hline Q22 & $\begin{array}{l}\text { Author: If this is not a one-page article please supply the } \\
\text { first and last pages for this article in reference [95]. }\end{array}$ & \\
\hline$\overline{Q 23}$ & Author: Please provide the full detail of Reference 138. & \\
\hline$\overline{Q 24}$ & $\begin{array}{l}\text { Author: Please provide volume number and page range } \\
\text { in reference [174]. }\end{array}$ & \\
\hline $\mathbf{Q 2 5}$ & $\begin{array}{l}\text { Author: Please check the authors' biographies as typeset } \\
\text { for correctness. }\end{array}$ & \\
\hline
\end{tabular}

